\title{
Styrene and Bioaerosol Removal from Waste Air with a Combined Biotrickling Filter and DBD-Plasma System
}

\author{
Steffen Helbich ${ }^{1}$, Daniel Dobslaw ${ }^{1, *(1)}$, Andreas Schulz ${ }^{2}$ and Karl-Heinrich Engesser ${ }^{1}$ \\ 1 Department of Biological Waste Air Purification, Institute of Sanitary Engineering, \\ Water Quality and Solid Waste Management, University of Stuttgart, Bandtäle 2, 70569 Stuttgart, Germany; \\ steffen.helbich@iswa.uni-stuttgart.de (S.H.); karl-h.engesser@iswa.uni-stuttgart.de (K.-H.E.) \\ 2 Institute of Interfacial Process Engineering and Plasma Technology, University of Stuttgart, \\ Pfaffenwaldring 31, 70569 Stuttgart, Germany; andreas.schulz@igvp.uni-stuttgart.de \\ * Correspondence: daniel.dobslaw@iswa.uni-stuttgart.de; Tel.: +49-711-685-65406
}

Received: 15 September 2020; Accepted: 2 November 2020; Published: 6 November 2020

\begin{abstract}
A combined system of a biotrickling filter and a non-thermal plasma (NTP) in a downstream airflow was operated for 1220 days for treatment of emissions of styrene and secondary emissions of germs formed in the biological process. The biotrickling filter was operated at variable inlet concentrations, empty bed residence times (EBRT), type and dosage of fertilizers, irrigation densities, and starvation periods, while dielectric barrier discharge and corona discharge were operated at different specific input energy levels to achieve optimal conditions. Under these conditions, efficiencies in the removal of volatile organic compounds (VOCs), germs and styrene of 96-98\%, 1-4 log units and 24.7-50.1 $\mathrm{g} \mathrm{C} \mathrm{m}^{-3} \mathrm{~h}^{-1}$ were achieved, respectively. Fluid simulations of the NTP and a germ emission-based clocking of the discharge reveal further energy saving potentials of more than $90 \%$. The aim of an energy-efficient elimination of VOCs through a biotrickling filter and of secondary germ emissions by a NTP stage in a downstream airflow for potential re-use of purified waste gas as process gas for industrial application was successfully accomplished.
\end{abstract}

Keywords: styrene; biotrickling filter; non-thermal plasma; dielectric barrier discharge; demister; bioaerosols; waste air treatment; VOC; sterilization

\section{Introduction}

Styrene is one of the most hazardous lipophilic volatile organic compounds (VOCs), causing irritations of eyes, skin, and the respiratory system. It may cause neurotoxic, hematological, cytogenetic, and carcinogenic effects in humans and was classified as a group IIb compound by the International Agency on Research on Cancer (IARC) [1,2]. Styrene is widely used in the industrial production of plastics, polymers, latex paints, gelcoats, rubber, and solvents, but also in drip processes and coatings in the automobile industry. The global production capacity of styrene monomers was about 14 million tons in 1992, but reached 36.7 million tons in 2018 [3,4], equivalent to a market volume of USD 48.8 billion in 2017 and USD 43.3 billion in 2019 owing to declining prices. Due to its multiple applications and high vapor pressure, styrene is predominantly released into the environment by gaseous emissions, typically in the range of $50-1800 \mathrm{mg} \mathrm{m}^{-3}$ ([5-8] as well as results from the authors' own measurements at two fibre-reinforced plastics manufacturers and a drip process). These gas streams may be treated by waste gas treatment techniques such as incineration, adsorption, or biological processes, where the latter has revealed significant advantages in construction and operational costs.

The microbial metabolism of styrene has been the subject of intensive research and was previously described in [9-14]. However, biodegradability is severely limited by the transition of gaseous styrene 
into the aqueous phase and subsequently into the biological phase. Hence, various studies deal with biodegradation of styrene in biotrickling filters and biofilters with the optional addition of solubilizers, as exemplarily listed in Table 1.

In summary, it can be stated that, depending on the existing crude gas concentration and empty bed residence time (EBRT), styrene can be degraded with elimination rates of between $1.6-120 \mathrm{~g} \cdot \mathrm{m}^{-3} \cdot \mathrm{h}^{-1}$ in biofilters and 7.3-336 $\mathrm{g} \cdot \mathrm{m}^{-3} \cdot \mathrm{h}^{-1}$ in biotrickling filters. The degradation capacity can be further increased by adding suitable fertilizers [15], inductors (e.g., $\mathrm{H}_{2} \mathrm{O}_{2}$ ) [1] or solubilizers (silicone oil, Triton X-100) [1,16-19].

Plasma is a gaseous state in which atoms or molecules are completely or partially ionized. In technical applications, plasmas are formed by the acceleration of electrons as reactants in electrical fields, where the method of a dielectric barrier discharge (DBD) is mainly favored due to its process stability and adaptability to high volume flows. During dielectric discharge, reactive radicals, cations, anions and metastable molecules are formed, which are capable of reducing VOC emissions, odors and bioaerosols through oxidative reaction mechanisms. At first, environmental application NTPs were used for the treatment of military waste in 1984-1986 [20,21]. The application of NTPs has been investigated for a wide range of VOCs and inorganic air pollutants both on a laboratory scale [22] and a pilot scale [23]. However, the main disadvantage of NTP processes is a correlation between energy demand and the concentration of contaminants. Hence, energy demand and operating costs of the NTP increase with concentrations. Considering energy-efficient operation, NTP processes are mainly used for partial oxidation and hydrophilization of lipophilic and, thus, hardly biodegradable contaminants [24-26]. For odor treatment and bioaerosols, however, they are very cost-effective [27-32]. Besides strain-specific aspects, the efficiency strongly depends on the growth conditions of the organisms as well as the properties of the adherent surface $[33,34]$.

Despite their desirability in terms of energy efficiency, sustainability and operating costs, combinations of NTP and biological treatment have been sparsely investigated. There are two options for combining both technologies. By using NTP as a pre-treatment, waste gas compounds are transformed into components of higher bioavailability. Hence, more compact designs of biofiltration processes at higher treatment efficiencies are possible. In contrast, NTP as a post-treatment technique is used for finishing off residual VOC, odors, and the sterilization of the clean gas out of the biofiltration process.

NTP upstream processes in combination with biofilters were investigated for treatments of limonene [35], mixtures of terpenes, chlorobenzene, trichloromethane, phenol and odor [36], mixtures of ethanol, ethyl acetate, benzene, toluene and octane [37], as well as mixtures of toluene, $n$-heptane, $p$-xylene, ethylbenzene, and benzene [26]. Combinations of NTP and a biotrickling filter were used in the treatment of dimethyl disulfide (DMDS) [38], chlorobenzene [39], 1,2-dichloroethane [40], butanone [41], 3-pentanone [41], benzene [41], toluene [41], ethylbenzene [41], $n$-hexane [41], methyl tert-butyl ether (MTBE) [41], mixtures of 1,2-dichloroethane and $n$-hexane [40], mixtures of toluene, $p$-xylene and ethylene [42], mixtures of styrene and $o$-xylene [43] or mixtures of $n$-butanol, 2-butoxyethanol and odor [22]. This process combination was also proposed by Zhu et al. [44] for chlorobenzene.

The approach of NTP-supported sterilization of biologically pre-treated exhaust air has so far only been investigated for a biofilter treating mixtures of limonene, butanone, DMDS, toluene and ethyl acetate [45], or a mixture of dimethyl sulfide, carbonyl sulfide, DMDS, methane and odor [46]. A combination of biotrickling filter and downstream NTP stage has not yet been tested.

The aim of this study was, in a first step, to quantitatively treat styrene as an exhaust air pollutant through a biotrickling filter and to determine the operating parameters relevant for process optimization, such as contact time, irrigation density, fertilizer type, and fertilizer dosage. In a second step, the effect of operating parameters on germ emissions and sterilization efficiency of the NTP stage was tested. The anticipation of an upcoming introduction of limit values regarding bioaerosol emissions in German federal law and the requirement for disinfection, if the treated air was to be re-used in ventilation of workplaces, will make the secondary treatment stage mandatory for biological waste air treatment. 
Additionally, the NTP stage can be used for VOC-abatement. Synergistic effects from the combined treatment steps are aspired and to be quantified.

Table 1. Recent examples of styrene removal by biotrickling filter (BTF) and biofilter (BF) processes. $\mathrm{C}_{\mathrm{in}}$ : inlet concentration; EBRT: empty bed residence time (s); RE: removal efficiency (\%); EC: elimination capacity $\left(\mathrm{g} \cdot \mathrm{m}^{-3} \cdot \mathrm{h}^{-1}\right)$; index $\mathrm{C}$ : listed as styrene-C.

\begin{tabular}{|c|c|c|c|c|c|}
\hline Bioreactor & $\mathrm{C}_{\mathrm{in}}$ & EBRT & RE & EC & Reference \\
\hline BTF & $0.2-1.0 \mathrm{~g} \cdot \mathrm{m}^{-3}$ & $41-62$ & $78-94$ & 26.1-70.7 & [47] \\
\hline BTF & $55-312 \mathrm{mg} \mathrm{C} \cdot \mathrm{m}^{-3}$ & $15-30$ & $\approx 90$ & $7.0-31.7_{C}$ & {$[48]$} \\
\hline BTF & $2-4 \mathrm{~g} \cdot \mathrm{m}^{-3}$ & $30-70$ & $27.2-61.8$ & $63.6-130.6$ & [49] \\
\hline $\begin{array}{l}\text { BTF without silicon oil } \\
\text { BTF with silicon oil } \\
\text { BTF without silicon oil }\end{array}$ & $55-323 \mathrm{mg} \mathrm{C} \cdot \mathrm{m}^{-3}$ & $\begin{array}{l}15 \\
15 \\
30\end{array}$ & $\begin{array}{l}18-64 \\
57-89 \\
87-97\end{array}$ & $\begin{array}{l}8.3-32.3_{C} \\
11.6-43.9_{C} \\
19.4-21.6_{C}\end{array}$ & [18] \\
\hline BTF & $195-2112 \mathrm{mg} \cdot \mathrm{m}^{-3}$ & 28-113 & $72.3-100$ & $26.8-48.6$ & {$[50]$} \\
\hline BTF & $161-2390 \mathrm{mg} \cdot \mathrm{m}^{-3}$ & 21 & $83-98.7$ & $170-300$ & [51] \\
\hline BTF & $107 \mathrm{mg} \cdot \mathrm{m}^{-3}$ & 31 & 93 & 11.6 & [52] \\
\hline $\begin{array}{l}\text { BTF without silicon oil } \\
\text { BTF with silicon oil }\end{array}$ & $330 \mathrm{mg} \mathrm{C} \cdot \mathrm{m}^{-3}$ & 20 & $\begin{array}{l}69-79 \\
64-68\end{array}$ & $\begin{array}{l}38-42_{C} \\
35-41_{C}\end{array}$ & [16] \\
\hline BTF with solubilizer & $120-760$ ppm & 60 & $72-100$ & $30.7-139$ & {$[1]$} \\
\hline $\begin{array}{l}\text { BTF without } \mathrm{H}_{2} \mathrm{O}_{2} \\
\text { BTF with } \mathrm{H}_{2} \mathrm{O}_{2}\end{array}$ & $\begin{array}{l}260 \mathrm{ppm} \\
263 \mathrm{ppm}\end{array}$ & $\begin{array}{l}15 \\
15\end{array}$ & $\begin{array}{l}11 \\
94\end{array}$ & $\begin{array}{c}28 \\
250\end{array}$ & [1] \\
\hline $\begin{array}{l}\text { BTF without X-100 } \\
\text { BTF with X-100 }\end{array}$ & $250 \mathrm{mg} \cdot \mathrm{m}^{-3}$ & $7.5-30$ & $\begin{array}{l}50-87 \\
82-96\end{array}$ & $\begin{array}{l}56.8-100.9 \\
62.7-165.4\end{array}$ & [17] \\
\hline BTF & $0.13-14 \mathrm{~g} \cdot \mathrm{m}^{-3}$ & $20-91$ & $50-90$ & $83-336$ & {$[53]$} \\
\hline $\begin{array}{l}\text { BTF without silicon oil } \\
\text { BTF with silicon oil }\end{array}$ & $0.8-3.3 \mathrm{~g} \cdot \mathrm{m}^{-3}$ & 60 & $\begin{array}{l}28-100 \\
68-100 \\
\end{array}$ & $\begin{array}{c}29-70 \\
29-110\end{array}$ & [19] \\
\hline BTF & $0.24-1.99 \mathrm{~g} \cdot \mathrm{m}^{-3}$ & 40-135 & $9.4-100$ & $36.8-85$ & {$[54]$} \\
\hline $\begin{array}{l}\text { BTF without silicon oil } \\
\text { BTF with silicon oil }\end{array}$ & $\begin{array}{c}1.7-8.0 \mathrm{~g} \cdot \mathrm{m}^{-3} \\
0.8-23.8 \mathrm{~g} \cdot \mathrm{m}^{-3}\end{array}$ & $20-91$ & $\begin{array}{l}24-100 \\
41-100\end{array}$ & $\begin{array}{c}0-172.8 \\
0-670\end{array}$ & [55] \\
\hline $\begin{array}{l}\text { BTF with urea } \\
\text { BTF with nitrate }\end{array}$ & $167-2000 \mathrm{mg} \mathrm{C} \cdot \mathrm{m}^{-3}$ & 60 & $\begin{array}{l}88.3 \\
56.8\end{array}$ & $\begin{array}{l}57.6_{C} \\
37.5_{C}\end{array}$ & [56] \\
\hline BTF with nitrate & 50-330 ppm & $45-121$ & $57-100$ & $9.80-24.5$ & [57] \\
\hline $\begin{array}{l}\text { BF with ammonia } \\
\text { BF with ammonia } \\
\text { BF with ammonia } \\
\text { BF with nitrate }\end{array}$ & $\begin{array}{c}840-920 \mathrm{mg} \cdot \mathrm{m}^{-3} \\
840-920 \mathrm{mg} \cdot \mathrm{m}^{-3} \\
920-1020 \mathrm{mg} \cdot \mathrm{m}^{-3} \\
500-3390 \mathrm{mg} \cdot \mathrm{m}^{-3}\end{array}$ & $\begin{array}{l}63.6 \\
42.4 \\
21.2 \\
127\end{array}$ & $\begin{array}{c}95.6-98.6 \\
80.5-89.9 \\
88.9-62.3 \\
65.1-100\end{array}$ & $\begin{array}{c}52.4-58.2 \\
91.2-103.5 \\
73.6-116.2 \\
14.5-50.4\end{array}$ & [15] \\
\hline $\mathrm{BF}$ & $0.1-0.9 \mathrm{~g} \cdot \mathrm{m}^{-3}$ & 9-18 & 90 & $22-27$ & [58] \\
\hline $\mathrm{BF}$ & $678 \mathrm{mg} \cdot \mathrm{m}^{-3}$ & 30 & $96-98$ & 79 & [59] \\
\hline $\mathrm{BF}$ & $50-1200 \mathrm{mg} \cdot \mathrm{m}^{-3}$ & 58-108 & $20-98$ & $3-30$ & [60] \\
\hline $\mathrm{BF}$ & $100-600 \mathrm{mg} \cdot \mathrm{m}^{-3}$ & 27-108 & - & $\leq 50$ & [61] \\
\hline $\mathrm{BF}$ & $700-3600 \mathrm{mg} \cdot \mathrm{m}^{-3}$ & $22-100$ & $50-100$ & $10-120$ & [62] \\
\hline $\mathrm{BF}$ & $55-550 \mathrm{mg} \cdot \mathrm{m}^{-3}$ & 30 & 95-100 & $6.6-63$ & [63] \\
\hline $\mathrm{BF}$ & $45 \mathrm{mg} \cdot \mathrm{m}^{-3}$ & 10 & $>80$ & $12.8-16$ & [64] \\
\hline $\mathrm{BF}$ & $0.1-2.4 \mathrm{~g} \cdot \mathrm{m}^{-3}$ & $25-93$ & $9.4-100$ & $17.3-76$ & [65] \\
\hline
\end{tabular}




\section{Materials and Methods}

\subsection{Design of the Pilot-Scale Waste Air Treatment Plant}

The waste air treatment plant consisted of two treatment stages in three configurations, a biotrickling filter (BTF) and a consecutive dielectric barrier discharge non-thermal plasma (DBD) in (a) inline mode, (b) by-pass mode, or (c) a corona plasma in inline mode, as shown in Figure 1. The BTF column was equipped with Hiflow rings as a filling bed and operated for 1220 days with a crude gas of styrene monomer at final concentration levels of $100-400 \mathrm{mg} \mathrm{C} \mathrm{m}^{-3}$ with repeated inoculation until day 89 . The treatment plant was set up in a non-heated indoor area with ambient temperatures of $20 \pm 4{ }^{\circ} \mathrm{C}$ throughout the years. Temperature-related effects on the biocoenosis and analytics are hence negligible.
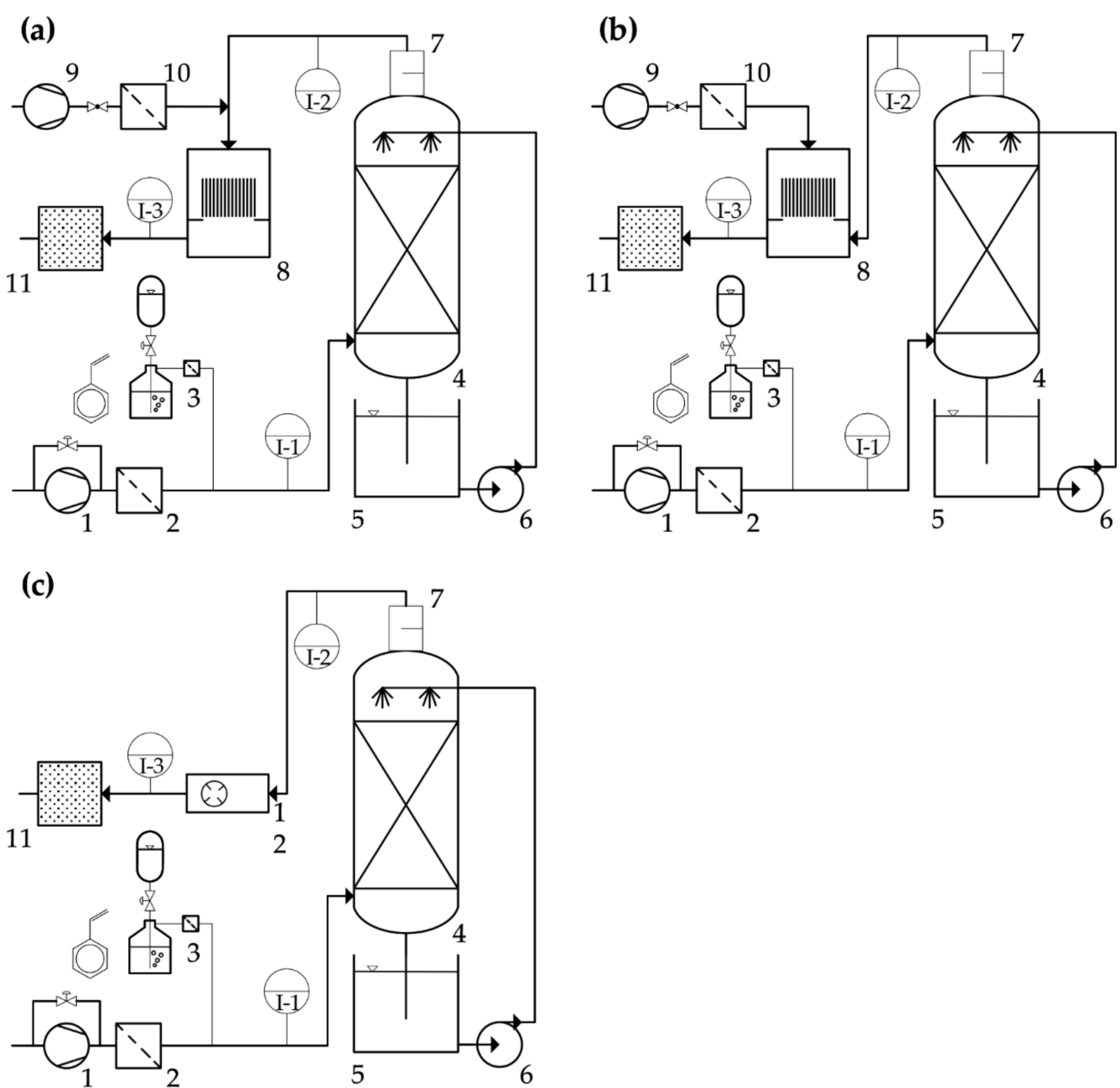

Figure 1. Flow chart of pilot-scale waste air treatment plant. Secondary stage configuration: (a) dielectric barrier discharge (DBD) in inline mode with (9) providing the diluting auxiliary air stream; (b) DBD in by-pass mode with (9) providing the plasma-activated air stream; (c) corona plasma in inline mode. (1) First lateral channel blower; (2) first F9 folded filter; (3) gaseous styrene generation; (4) BTF column; (5) regenerator basin; (6) recirculation pump; (7) demister; (8) DBD; (9) second lateral channel blower; (10) second F9 folded filter; (11) activated charcoal filter; (12) corona plasma (I-1) to (I-3) measurement points for volatile organic compounds (VOCs) and aerosols.

The column (material: polyethylene (PE); height, $2000 \mathrm{~mm}$; inner diameter, $500 \mathrm{~mm}$ ) was filled with $1700 \mathrm{~mm}$ of Hiflow rings (diameter, $25 \mathrm{~mm}$; material, PE; specific surface $214 \mathrm{~m}^{2} \cdot \mathrm{m}^{-3}$; Paul Rauschert GmbH \& Co. KG, Schleßlitz, Germany), equivalent to an effective filter bed volume of 
$330 \mathrm{~L}$. The packed column was directly attached to a regenerator basin, sized $500 \mathrm{~mm} \times 500 \mathrm{~mm} \times 800 \mathrm{~mm}$. The volume of the swamp phase was kept in the range of 120-140 L and was continuously aerated. $\mathrm{pH}$ conditions in the swamp phase were repeatedly checked, but no change occurred during the operation time. The package material was discontinuously sprayed by two full-cone nozzles (type TF-6; BETE Deutschland $\mathrm{GmbH}$, Bochum, Germany), installed in the head space of the column, for $1 \mathrm{~min}$ per $5 \mathrm{~min}$ and $1 \mathrm{~min}$ per $20 \mathrm{~min}$ with $53.3 \mathrm{~L} \mathrm{~min}^{-1}$ of recirculated aqueous phase out of the regenerator (irrigation density: 8.18 and $0.82 \mathrm{~m}^{3} \mathrm{~m}^{-2} \mathrm{~h}^{-1}$ ). The artificial waste air was generated by purging a carrier gas flow through liquid styrene at room temperature via a washing flask. Aerosols were held back by a fuel filter with a metal plate (type 18151, Hans Pfeffer Vertriebs mbH, Bodenwerder, Germany). The gaseous styrene was then mixed with clean air in a $5 \mathrm{~m}$ mixing path before entering the BTF. The clean air was provided by a lateral channel blower, prefiltered by an F9 folded filter (type minipleat; EMW filtertechnik GmbH, Diez, Germany). Crude gas concentration could be adjusted by regulating the carrier gas pressure via a membrane valve, and was varied between $100-400 \mathrm{mg} \mathrm{C} \mathrm{m}^{-3}$. This range reflects real applications, where styrene represents at least $99 \%$ of the occurring VOC load at comparable concentration levels [5-8]. The volume flow was set by another membrane valve. Volume flows and resulting empty bed residence times (EBRT) can be seen in Figure 2. Fertilizer was added as NPK 7-3-5 solution (1.5\% $\mathrm{NH}_{4}{ }^{+}-\mathrm{N}, 2.3 \% \mathrm{NO}_{3}{ }^{-}-\mathrm{N}, 3.2 \%$ urea, $3 \% \mathrm{P}_{\text {as }} \mathrm{P}_{2} \mathrm{O}_{5}, 5 \% \mathrm{~K}$ as $\left.\mathrm{K}_{2} \mathrm{O}\right)$, solution (CMI Blumendünger, terrasan Haus + Gartenbedarf $\mathrm{GmbH}$, Rain am Lech, Germany), or urea (Piagran, BayWa AG, Munich, Germany), as seen in Figure 2.

\subsection{Plasma Generators}

The DBD was set up and powered as described previously (lab-scale NTP, [23]), without the drawer and mineral adsorber. The ozone concentration could be varied by the tuning of the electrical power input.

(a) DBD inline mode: The air stream from the outlet of the biotrickling filter was converged with a diluting auxiliary air stream, provided by a second lateral channel blower, and prefiltered by an F9 folded filter (see above). The combined gas flow was connected via polypropylene (PP) piping (DN110) to the top flange of the DBD casing. A demister (type, PGM-4; length, $160 \mathrm{~mm}$; material, PP knitted fabric; Anselm GmbH \& Co. KG, Weißenburg, Germany) was installed in the piping, directly at the outlet of the BTF. The lateral channel blower, and therefore the auxiliary gas flow, could be regulated by a frequency converter. This strand could be shut off with a stop valve. The diluting gas stream was necessary to decrease humidity and secure stable plasma operation. This configuration created an inline mode of operation, where bioaerosols were conducted through the plasma generator, exposing microorganisms to the plasma, and emitted UV radiation.

(b) DBD by-pass mode: The air stream from the outlet of the biotrickling filter was connected via PP piping (DN110) to a bottom flange of the DBD casing. The now-separate auxiliary gas flow was connected to the top flange of the DBD casing. This configuration created a by-pass mode of operation, by mixing ozone into the gas stream coming from the BTF. This prevented flashovers in the DBD itself, which may have been caused by wet air at a relative humidity of 35 and above.

(c) Corona inline mode: The corona plasma generator was built in a square flow channel (diameter, $250 \mathrm{~mm}$; length, $700 \mathrm{~mm}$ ) with flanges, allowing it to be directly connected to the piping after the demister. This configuration created an inline mode of operation. By the nature of the plasma generation, higher relative humidity is tolerated. The generator was powered by a $400 \mathrm{~W}$ fixed output power supply; thus, the ozone output was fixed. In contrast to the large surface discharge of the DBD, the corona plasma occurs only at four spikes, arranged in a circle on an electrode ring.

The treatment plant was equipped with analytics as described below. 


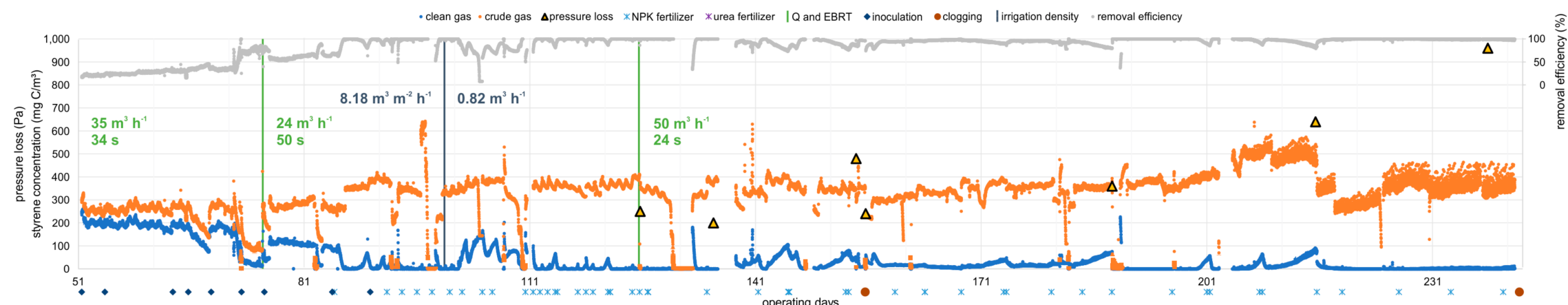

(a)

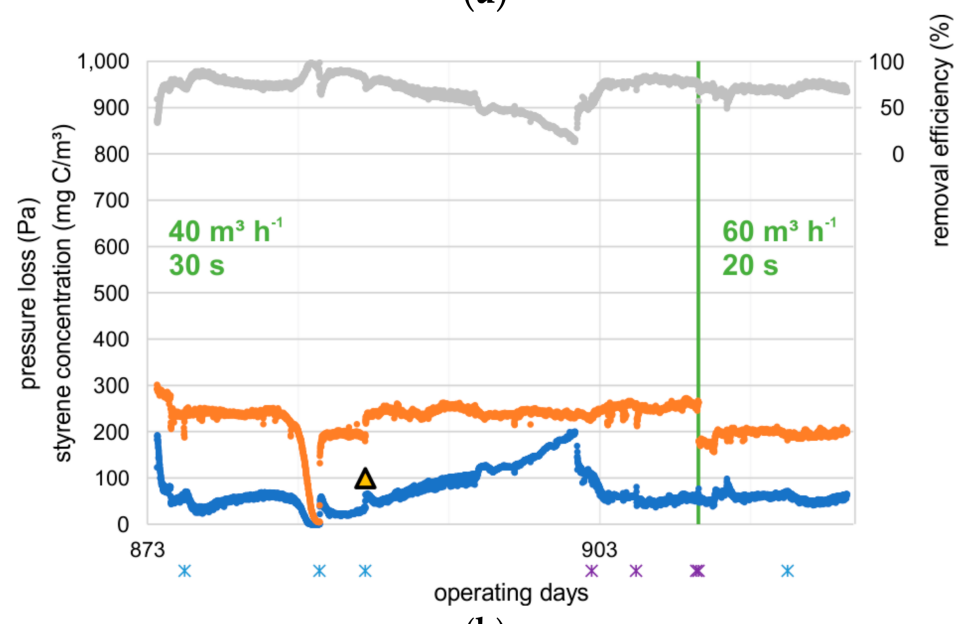

$(\mathbf{b})$

Figure 2. Crude and clean gas concentrations of total carbon, removal efficiency, pressure loss, volumetric flow rates and EBRT, irrigation density, time points of inoculation, time points of fertilizer dosage, and clogging events from selected periods of the operating time of the BTF for operating days (a) 51-241 and (b) 873-919. 


\subsection{Microbiology}

The BTF was inoculated with a liquid culture containing 17 different environmental isolates from the internal strain database (all risk group 1 according to Technical Rules for Biological Agents (TRBA) 466), capable of using styrene as a sole source of carbon and energy. The isolates were originally enriched from forest soil, agricultural soil, and activated sludge. The bacteria were cultivated in fed-batch cultures on a mineral salts medium (MM [66]) with styrene in the gas phase. Points of inoculation are depicted in Figure 2. Activated sludge may contain strains from risk groups 2 and above, and was therefore not suitable as inoculum, as it would have required an additional sterilization step to securely eliminate health risks for the researchers.

With a slit-to-agar impactor (see Section 2.4. Analytics), bioaerosol monitoring was conducted, where total colony forming units (CFU) of bacteria and total fungi were captured on nutrient broth (NB, Carl Roth GmbH + Co. KG, Karlsruhe, Germany) and dichloran-glycerol (DG18, Merck KGaA, Darmstadt, Germany) agar plates, respectively. Plates were incubated in the dark at $30{ }^{\circ} \mathrm{C}$ for $3-5$ days.

\subsection{Analytics and Calculations}

For VOC levels in both crude (sample point I-1) and clean (I-2) gas flame ionization detectors (FID) (2010T, Testa GmbH, Munich, Germany) equipped with heated sample gas lines at $180{ }^{\circ} \mathrm{C}$, polytetrafluoroethylene (PTFE) tubing $6 \mathrm{~mm}$ inner diameter (Testa $\mathrm{GmbH}$ ), and fuel filters (see above) for aerosol and dust protection of the FIDs were installed. FIDs were calibrated every month with artificial air, each with 0 ppm and 200 ppm n-propane (both basi Schöberl GmbH \& Co. KG, Rastatt, Germany). Removal efficiency (RE) of the BTF was calculated as follows:

$$
R E[\%]=100 \cdot \frac{1-C_{\text {out }}}{C_{\text {in }}}
$$

where: $C_{\text {in }}=$ inlet concentration $\left[\mathrm{mg}\right.$ carbon $\left.\mathrm{m}^{-3}\right] ; C_{\text {out }}=$ outlet concentration $\left[\mathrm{mg}\right.$ carbon $\left.\mathrm{m}^{-3}\right]$.

Two slit-to-agar impactors (FH6, Klotz GmbH \& Co. KG, Bad Liebenzell, Germany) with internal regulating suction pumps $\left(\mathrm{Q}=100 \mathrm{~L} \mathrm{~min}^{-1}\right.$, sampling time $10 \mathrm{~min}$ per plate) and rotary discs allowed time-resolved sampling of bioaerosols on different agar media (see Section 2.3. Microbiology). The impactors were connected to the PP piping in a horizontal position at I-2 and I-3.

Aerosols were monitored with a scatter light photometer (DustTrak DRX Aerosol Monitor 8533, TSI GmbH, Aachen, Germany) for simultaneous measuring of size-segregated mass fraction concentrations corresponding to particulate matter total size fractions PM1, PM2.5, PM4, PM10 and PM. Isokinetic sampling was conducted at I-2 with a defined nozzle on a gooseneck curve (both Paul Gothe $\mathrm{GmbH}$, Bochum, Germany), connected via an anti-static pipe (PTFE, inner diameter $8 \mathrm{~mm}$, outer diameter $10 \mathrm{~mm}, 10 \mathrm{~cm}$ length) to the photometer. An external regulating suction pump provided a constant volume flow of $3 \mathrm{~L} \mathrm{~min}^{-1}$. The nozzle width was calculated according to VDI guideline no. 2066 [67].

Air samples were taken at sample points I-2 and I-3. Styrene metabolites were analyzed by GC-MS, as previously described [23].

Ozone is produced in plasma by direct electron impact dissociation of the $\mathrm{O}_{2}$ molecule. The ozone concentrations in the exhaust gas were measured by absorption spectroscopy. Ozone has no electronic emission bands as such, but shows a strong absorption band around the wavelength of $254 \mathrm{~nm}$ [68]. The concentration c for the produced ozone is then calculated from the absorbance value at $254 \mathrm{~nm}$ using Beer Lambert law, with the following correlation [68]:

$$
\mathrm{CO}_{3}[\mathrm{ppm}]=\frac{10^{6} \cdot T}{273 \cdot p \cdot k \cdot l} \log \frac{I_{0}}{I}
$$

where: $T=$ temperature $(\mathrm{K}) ; p=$ total pressure; $k=$ extinction coefficient of ozone $=135 \mathrm{~cm}^{-1} \mathrm{~atm}^{-1}[68]$; $l=$ path length; $I_{0}=$ intensity with carrier gas only (air); $I=$ intensity with $\mathrm{O}_{3}$ present. 
An optical absorption arrangement with a UV light source and an optical spectrometer was set up to measure the built-up ozone in the exhaust stream. The UV light was produced by a deuterium lamp. Deuterium shows a very strong and wide emission spectrum in between the wavelengths of $180 \mathrm{~nm}$ to $300 \mathrm{~nm}$. These wavelengths are also emitted from the sun and absorbed by the ozone layer before they reach the earth. By using the deuterium lamp as the UV source on one side of the duct, and the optical probe on the other side, the absorption values across the outlet duct were measured for varying operating parameters. The scheme of the setup for this ozone absorption measurement is shown in Figure 3. Quartz lenses and quartz windows were used for this purpose, because glass would block most of the UV light below $300 \mathrm{~nm}$, while quartz has good transparency for wavelengths down to $165 \mathrm{~nm}$.

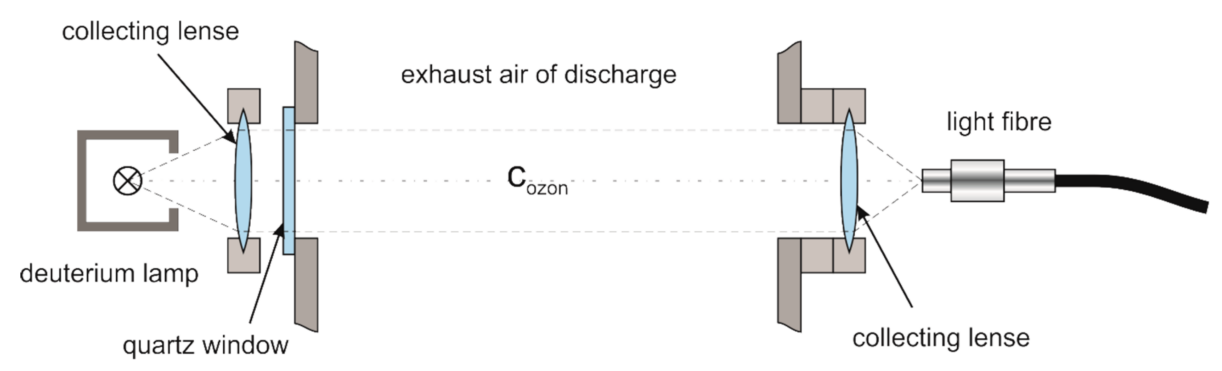

Figure 3. Scheme of the setup for the ozone absorption measurement. The absorption of the UV light from a deuterium lamp is determined using a spectrometer.

The beam path is sketched in the drawing. The UV light is parallelized via a quartz lens and radiated into the exhaust air area of the DBD discharge via a quartz coupling window. The parallel light beam is weakened by absorption when it passes through the exhaust air. On the opposite side, the parallelized beam is collected again by a quartz lens and focused on the entry point of the light guide. To obtain the best resolution from the system, the optical probe had to be placed at the focal point of the lens for $254 \mathrm{~nm}$, to collect the maximum amount of light.

The specific input energy (SIE) value allows for the comparison of different plasma processes. It describes the energy per unit volume supplied to the gas, standardized to a volume of $1000 \mathrm{~m}^{3}$, and was calculated accordingly:

$$
\operatorname{SIE}\left[k W h 1000 \mathrm{~m}^{-3}\right]=\frac{P}{Q \cdot 3,6}
$$

where: $P=$ power $(\mathrm{W}) ; Q=$ volume flow $\left(\mathrm{L} \mathrm{s}^{-1}\right)$.

\subsection{Simulation Software}

3D-CAD models were drawn with SolidWorks 2016 and corresponding fluid simulations were carried out with SolidWorks Flow Simulation 2016. Flow Simulation employs the $k-\epsilon$ model for the turbulent kinetic energy and its dissipation rate.

\subsection{Chemicals}

Technical grade styrene was supplied by Scharr (Friedrich Scharr KG, Stuttgart, Germany). Urea, as Piagran, was purchased from BayWa (BayWa AG, Munich, Germany).

\section{Results and Discussion}

\subsection{BTF}

The BTF was operated for 1220 days in total. Operating days of interest are shown in Figure 3. EBRT, nitrogen source and amount, as well as irrigation density were varied to investigate the effects on the treatment plant operation and removal efficiency (RE). 
Styrene tends to polymerize to a pale yellow solid when exposed to oxygen (polystyrene, PS). This form of the molecule is considered to be biologically inert. During the entire test period, no traces of the styrene polymer were found in laboratory cultures or in the treatment plant. Thus, on the one hand, the biological degradation is guaranteed and on the other hand, there is no danger of deposits forming in the treatment plant, which would result in a growing pressure loss. A polymerization in the plasma stage would be particularly critical, because here the discharge would be prevented.

\subsubsection{Influence of EBRT, Nitrogen Addition, Irrigation Density on Removal Efficiency, and} Starvation Period

The empty bed residence time of the biotrickling filter was changed to investigate the effect on RE. From day 1 to 75 , EBRT was $34 \mathrm{~s}$. To increase RE, EBRT was increased to $50 \mathrm{~s}$ for days 75 to 125. From day 125 until the end, EBRT was lowered to the final value of $24 \mathrm{~s}$ in order to test the performance of the system. With day 51, RE became quantitatively visible and started to rise steadily but moderately at a rate of $0.0125 \%$ per day. An increase in EBRT from day 75 onwards showed minor effects on degradation rates $(0.015 \%$ vs. $0.0125 \%$ per day). Although the addition of fertilizer (further to the nitrogen coming from the inoculation medium) during the first 51 days showed no effect (data not shown), probably owing to a low total biomass, additions from day 85 onwards had a major impact on RE. In just one and a half day, RE increased from $65 \%$ to almost $100 \%$ with a single dose of fertilizer ( $\left.10.5 \mathrm{~g} \mathrm{~N}_{\text {total }}\right)$. Further decreases in RE could always be countered with the addition of fertilizer. The amount of nitrogen needed could be calculated as a mean value from days 110-125 and 157-172 (RE $>90 \%$, pressure loss $<250 \mathrm{~Pa}$, stable styrene dosing) as $9.2 \mathrm{~g} \mathrm{~N}_{\text {total }} \mathrm{d}^{-1}$ at a freight rate of $12.46 \mathrm{~g} \mathrm{C} \mathrm{h}^{-1}$, resulting in a C:N ratio of 32.28:1. Once more, it is shown that, contrary to the common belief that nitrogen stays in the system and is recycled from dead biomass, it has to be fed in constantly. Denitrification in anoxic zones of the filling bed might deplete nitrogen as a source for biomass production and release molecular nitrogen via the exhaust air. Single isolates as well as mixed cultures have been reported to be able to consume styrene under anoxic conditions, although not much is known about the degradation pathways [69,70]. Six of the initial 17 styrene degrading strains used as inocula for the pilot-scale plant were found to be able to grow anaerobically on styrene. Their role in nitrogen consumption is subject of further research.

A change in irrigation density was undertaken at day 99 from $1.020 \mathrm{~m}^{3} \mathrm{~m}^{-2} \mathrm{~h}^{-1}$ to $0.153 \mathrm{~m}^{3} \mathrm{~m}^{-2} \mathrm{~h}^{-1}$. This action had no visible effect on RE, but decreased energy costs for the circulation pump as well as evaporation losses, and therefore decreased water consumption (not quantified).

On day 130, a controlled depletion of the substrate and consecutive break in dosing for 2.5 days were conducted to simulate, e.g., a break in production from the emitting factory. Oxygen supply through irrigation and air flow was set as before. After substrate reinitialization, it took the biocoenosis just $10 \mathrm{~h}$ to rise from $35 \%$ to $100 \%$ RE. This showed the resilience of the biocoenosis, and suggests that production breaks during weekends could be tolerated without a breakdown of the waste air treatment plant.

\subsubsection{Influence of Nitrogen Source on Removal Efficiency}

In this study, NPK 7-3-5 solution and urea solubilized in demineralized water were tested and used as the nitrogen source. As mentioned above, NPK was sufficient to meet the uptake requirements of the biocoenosis. On days 902 and 905, and twice on day 909, $10.5 \mathrm{~g} \mathrm{~N} \mathrm{~N}_{\text {total }}$ as urea was added to the regenerator basin. The mean values from days 901-915 (mean RE 71\%, pressure loss $100 \mathrm{~Pa}$, stable styrene dosing, change of EBRT at day 909 from $30 \mathrm{~s}$ to $20 \mathrm{~s}$ ) were $3 \mathrm{~g} \mathrm{~N}_{\text {total }} \mathrm{d}^{-1}$ at a freight rate of $10.85 \mathrm{~g} \mathrm{C} \mathrm{h}^{-1}$, resulting in a C:N ratio of 86.64:1. On the one hand, compared to NPK, nitrogen demand for urea was three times lower. On the other hand, RE during urea dosing $(71 \%$, decrease from $73 \%$ to $68 \%$ after decrease in EBRT at day 909) was $26 \%$ lower than during reference periods of NPK dosing (97\%). It can be assumed, that the bioavailability for NPK is higher, due to the reduced 
need for urea hydrolysis. Table 2 summarizes REs and elimination capacities of representative time periods with stable operation with respect to inlet concentration, EBRT and nitrogen source.

Table 2. Results of styrene removal by the biotrickling filter (BTF) process as mean values over respective time periods with stable operation. $\mathrm{C}_{\mathrm{in}}$ : inlet concentration $\left(\mathrm{mg} \mathrm{C} \cdot \mathrm{m}^{-3}\right)$; EBRT: empty bed residence time (s); RE: removal efficiency (\%); EC: elimination capacity $\left(\mathrm{g} \mathrm{C} \cdot \mathrm{m}^{-3} \cdot \mathrm{h}^{-1}\right)$; NPK: fertilizer 7-3-5 solution.

\begin{tabular}{cccccl}
\hline C $_{\text {in }}$ & EBRT & RE & EC & Bioreactor/N-Source & Reference \\
\hline 361 & 50 & 98 & 25.9 & BTF/NPK & this study \\
\hline 344 & 24 & 96 & 50.1 & BTF/NPK & this study \\
\hline 252 & 30 & 78 & 23.8 & BTF/urea & this study \\
\hline 195 & 20 & 70 & 24.7 & BTF/urea and subsequent NPK & this study \\
\hline
\end{tabular}

Costs for NPK were at $28 € \mathrm{~kg}^{-1} \mathrm{~N}_{\text {total }}$, while urea was significantly cheaper at $1 € \mathrm{~kg}^{-1} \mathrm{~N}_{\text {total }}$ (both prices might be lower for bulk purchases). This clearly favors urea to be the nitrogen source of choice, but if legal limit values are not met with this nitrogen source, additional sources or substitutes would have to be considered. For instance, these could be $\mathrm{NH}_{4}-\mathrm{N}$ or $\mathrm{NO}_{3}-\mathrm{N}$, as found in ASS (18.5-7.5), SSA (21-0), or KAS (13.5-13.5) fertilizers, although $\mathrm{NO}_{3}-\mathrm{N}$ is likely to yield lower REs than $\mathrm{NH}_{4}-\mathrm{N}[15,56]$.

If urea were to be used as sole nitrogen source, further supplementing of a phosphorous source would be necessary. No tests were undertaken to measure the demand, as no limiting effects became obvious during urea dosing. There was probably enough phosphorous present in the system from the NPK fertilizer. An estimated demand from both NPK dosing periods would be $13 \mathrm{mg} \mathrm{P}_{\text {total }}$ per $\mathrm{g} \mathrm{C}$ or lower.

\subsubsection{Pressure Loss and Clogging Events}

A disadvantage of biological treatment is the possibility of clogging events, which require elaborate and time-consuming maintenance [71]. Two clogging events in the BTF occurred. The first event (day 154) was resolved with anti-clogging measures after reaching 480 Pa pressure loss. Manual mixing of the Hiflow rings and purging of the filling bed with high-pressured water removed enough biomass to half the pressure loss. However, a desired pressure loss of $100 \mathrm{~Pa}$ and below could not be reached despite these measures. The second clogging event was allowed to develop to full extent to simulate an exemplary crash caused by neglectful operation. It took just another 84 days (day 238) to reach 960 Pa pressure loss. Here, the biomass was too dense to proceed as before, even when continuously washed with $1 \mathrm{M} \mathrm{NaOH}$ for $6 \mathrm{~h}$. The package as a whole had to be removed from the column and the Hiflow rings were mechanically washed before reinserted.

\subsubsection{Trickling Filter Fly Infestation}

During days 267-813, an infestation of Psychoda alternta larvae and adult flies (so called trickling filter fly) used the biofilm as a habitat and food source. Consequently, the performance dropped to almost zero within approx. 24 days. Biocoenosis and flies roughly followed the Lotka-Volterra predator-prey model. Several attempts in pest control were tried, namely: adding 2-chlorotoluene to the crude gas $\left(\sim 50 \mathrm{mg} \mathrm{C} \mathrm{m}^{-3}\right)$ to poison adults and larvae; adding acetamiprid $\left(15 \mathrm{mg} \mathrm{L}^{-1}\right)$ to the circulation water to poison adults and larvae; adding tensides to the regenerator basin to decrease surface tension and subsequently drown adults; and adding the juvenile hormone analog $S$-hydroprene ( $3 \mathrm{ng} \mathrm{L}^{-1}$ ) to the circulation water in order to prevent the maturation of the larvae and subsequently breaking the life cycle. All measures failed (data not shown). In the end, the complete packing material and circulation water had to be changed, column and piping cleaned and the BTF as a whole system was restarted with fresh inoculum at day 814 . 


\subsection{DBD-Plasma Operation}

The DBD-plasma generator could be operated in inline as well as in by-pass mode. Therefore, it was important to measure ozone output, because in by-pass mode short-lifetime OH-radicals and UV light do not contribute to VOC abatement or sterilization. Furthermore, hydraulic properties inside the plasma casing were assessed to identify specific input energy (SIE)-decreasing potential.

\subsubsection{Ozone Output}

Ozone in the exhaust air was measured as described above. In Figure 4, the spectrum of the pure air and the spectrum of ozone-containing air are shown. The intensity curves with pure air and air enriched with ozone are recorded with the spectrometer and mathematically calculated.

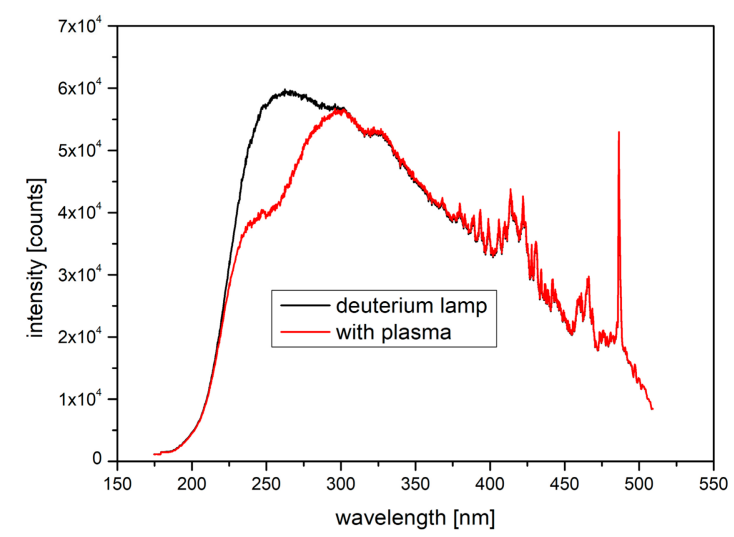

Figure 4. The deuterium lamp emits a spectrally wide UV light. The intensity curves with pure air and air enriched with ozone differ due to the absorption of ozone, with a broad band around $254 \mathrm{~nm}$.

Various frequencies were tested in combination with various power outputs from the generator, and the absorption spectra were recorded for each of the variations. In Figure 5, the measured data with respect to frequency and power input is plotted against the calculated ozone concentrations in $\mathrm{ppm}$. The ozone concentrations are not seen to be changing with varying frequencies, but only increase proportionally to power input. The experiments produced a peak ozone yield of ca. $45 \mathrm{~g} \mathrm{kWh}^{-1}$, which is in accordance with values reported for dry air $\left(15-22 \mathrm{kWh} \mathrm{kg}^{-1},[72]\right)$.

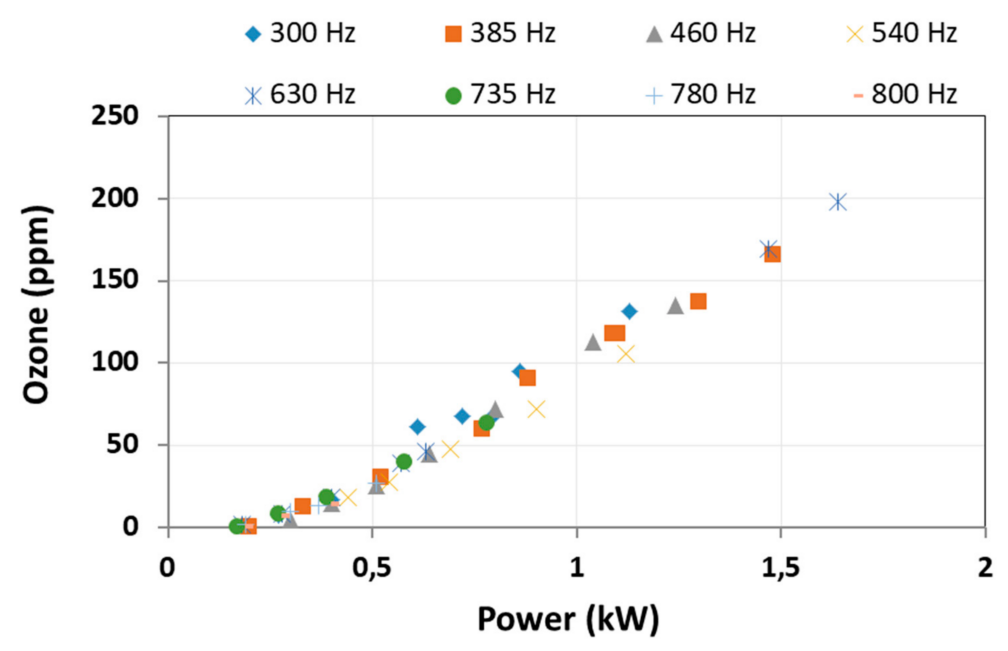

Figure 5. The ozone concentration in ppm is plotted against the power input for different frequencies. Concentrations of ozone are not seen to be changing with varying frequencies, but only increase proportionally to power input. 


\subsubsection{Hydraulic Flow Assessment of the Plasma Module}

A hydraulic flow simulation was conducted in order to identify SIE-decreasing potential. Figure 6 shows (a) inline and (b) by-pass modes of operation at maximum volumetric flow rates as used for sterilization in this study.
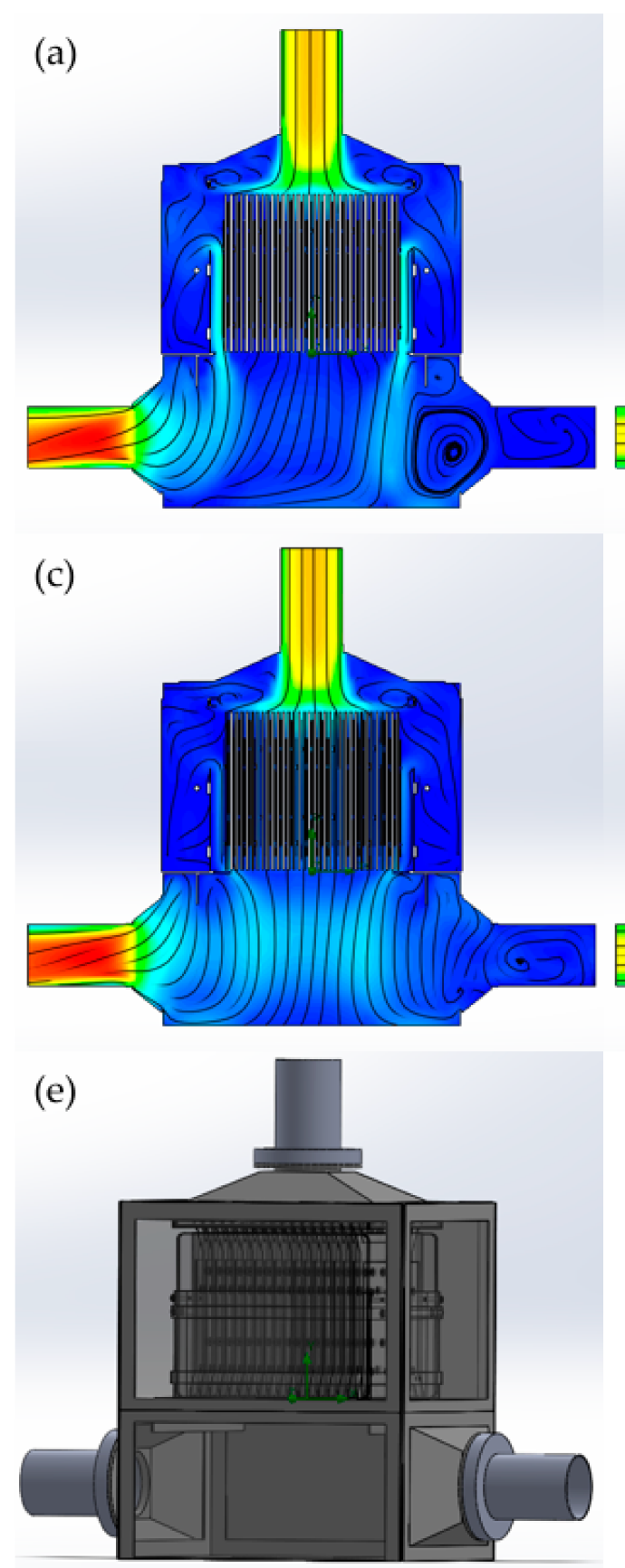
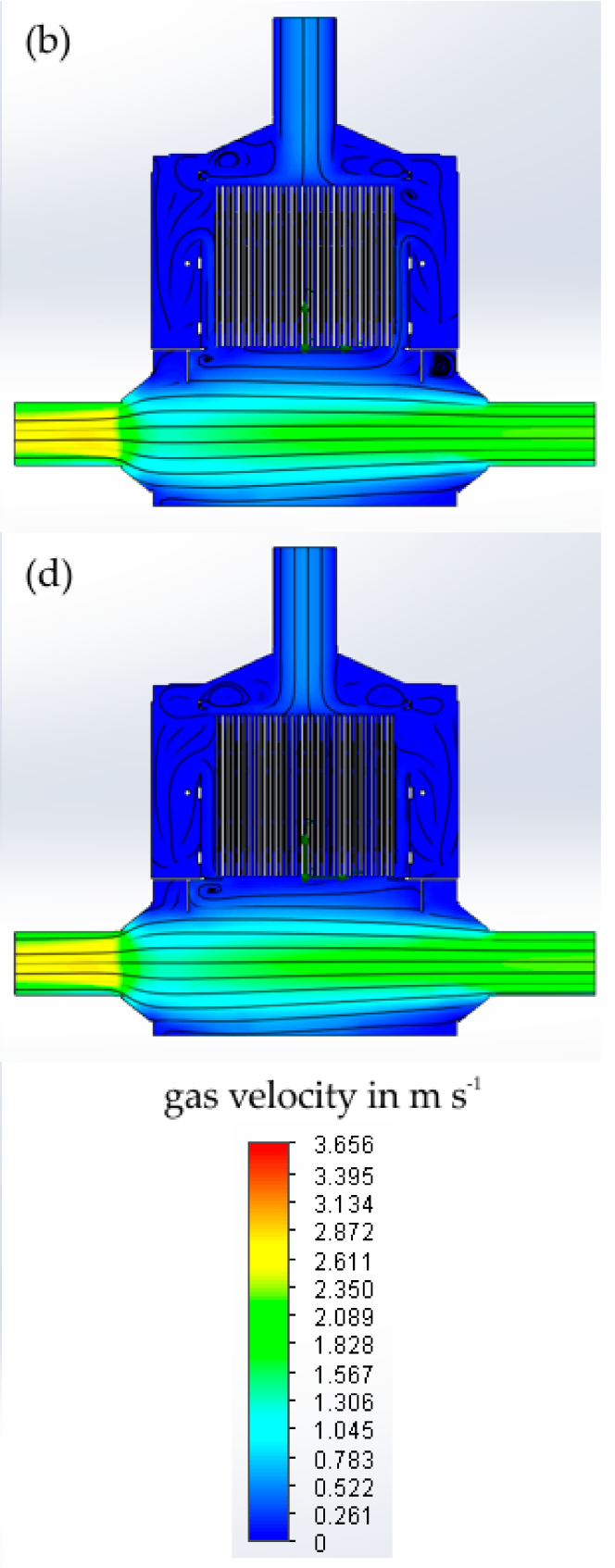

Figure 6. Hydraulic flow in plasma casing. Inline mode: diluted air stream from BTF passes through the DBD (top to bottom left) with actual (a) basket-supporting plate, and simulated reduced (c) outlet cross section. By-pass mode: Auxiliary air stream passes through the DBD (top) and mixes with the air stream from the BTF (bottom right to left) with actual (b) basket-supporting plate, and simulated reduced (d) outlet cross section. (e) 3D model of casing with DBD module.

Parameters were set as follows: adiabatic walls with a roughness of 0 ; volumetric flow rates at $30{ }^{\circ} \mathrm{C}$ and $80 \mathrm{~m}^{3} \mathrm{~h}^{-1}$ for inline and $60 \mathrm{~m}^{3} \mathrm{~h}^{-1}$ with $8.9 \mathrm{~m}^{3} \mathrm{~h}^{-1}$ auxiliary flow for by-pass operation; 
and outlets at atmospheric pressure. The simulations illustrate streams around the sides of the DBD (inline: $1.0-1.3 \mathrm{~m} \mathrm{~s}^{-1}$; by-pass: $0.15-0.25 \mathrm{~m} \mathrm{~s}^{-1}$ ), as the pressure loss over the stack of dielectric barriers and electrodes (distance $2 \mathrm{~mm}$ ) is higher than between outer electrodes and basket walls (distance $22 \mathrm{~mm}$ ). A smaller hole in the basket-supporting plate would force the air stream coming from the top inlet almost entirely through the DBD, resulting in more microorganisms coming into contact with the plasma in inline mode (c), or yielding more ozone from the auxiliary stream in by-pass mode (d), therefore increasing sterilization efficiency at lower SIE values. However, the opening cannot be cut too small, or unwanted discharges may occur between the upper electrodes and the plasma casing. The optimum distances must be assessed empirically.

\subsubsection{DBD for VOC Abatement}

Application for VOC abatement was not necessary when the BTF ran on maximum RE. Therefore, continuous operation of DBD should be avoided in terms of operational costs. Nevertheless, metabolite analysis via GC-MS was performed at higher styrene levels, showing a transformation of styrene both to $\mathrm{CO}_{2}$ and organic metabolites, and prevalent benzaldehyde, hexane aldehyde, heptane aldehyde [22]. At the tested crude gas concentrations, styrene was also transformed to these metabolites, showing lower toxicity than the educt. Therefore, emissions of these metabolites are less critical. Formaldehyde, as a decomposition product from the styrene ozonide formed by a Criegee reaction, could not be identified.

\subsection{Bioaerosols: Monitoring and Reduction}

Bioaerosols came into focus as a source of potential health risk. The recent amendment to the 42nd BImSchV and the planned incorporation of a mandatory reduction plan for bioaerosol emissions into the next version of the German Technical Instructions on Air Quality Control (TA-Luft) show its relevance. This will result in considerable increases in investment for existing and planned biological treatment plants, as additional treatment steps become necessary. Here, we investigated bioaerosol emissions from the BTF and possible reduction methods, namely a demister, DBD plasma, and corona plasma.

\subsubsection{Demister}

Aerosols were measured with a scatter light photometer (see Section 2.4. Analytics) at sampling point I-2. Over a period of one hour (operating day 120), the irrigation activity of the circulation pump could be mapped as particulate matter (PM total) (Figure 7a). During this time, irrigation was set to one minute on, 20 min off (gas velocity in headspace of the BTF column was $0.034 \mathrm{~m} \mathrm{~s}^{-1}$ and $0.78 \mathrm{~m} \mathrm{~s}^{-1}$ in the piping, crude gas concentration $360 \mathrm{mg} \mathrm{C} \mathrm{m}^{-3}, \mathrm{RE}=98 \%$ ). Aerosols could be detected instantly after switching on the pump, for a time span of about $95 \mathrm{~s}$. This indicates that aerosols were still present in the headspace of the column half a minute after the circulation pump stopped and were released later. During the remaining $19.5 \mathrm{~min}$, no particulate matter could be detected, therefore no aerosols were released. The photometer enabled simultaneous measuring of size-segregated mass fraction concentrations. Taking a closer look at the second irrigation interval (Figure 7b), it can be seen that a major part of PM total was comprised of the PM1 fraction, where the mean mass fraction over all three peaks was $81.5 \%$. Bacteria typically have a diameter of $1 \mu \mathrm{m}$ and therefore can be attributed to PM1. It was expected that recorded aerosols would be bioaerosols.

This could be corroborated with results of the slit-to-agar impactor (see Section 2.4. Analytics) measurements. Figure 8a shows an NB agar plate used at sample point I-2. With the time resolved capturing it was possible to align the results of both measurement techniques. The impactor turned the plate one time per $10 \mathrm{~min}$, where $95 \mathrm{~s}$ are equal to a segment of $57^{\circ}$. Here, the colonies are distributed more densely. Sparse colonies outside the section can be assigned to impacts from lateral gas flow. It can be concluded that the retention of bioaerosols or their sterilization only has to take place during the irrigation interval and a buffer time shortly afterwards. 

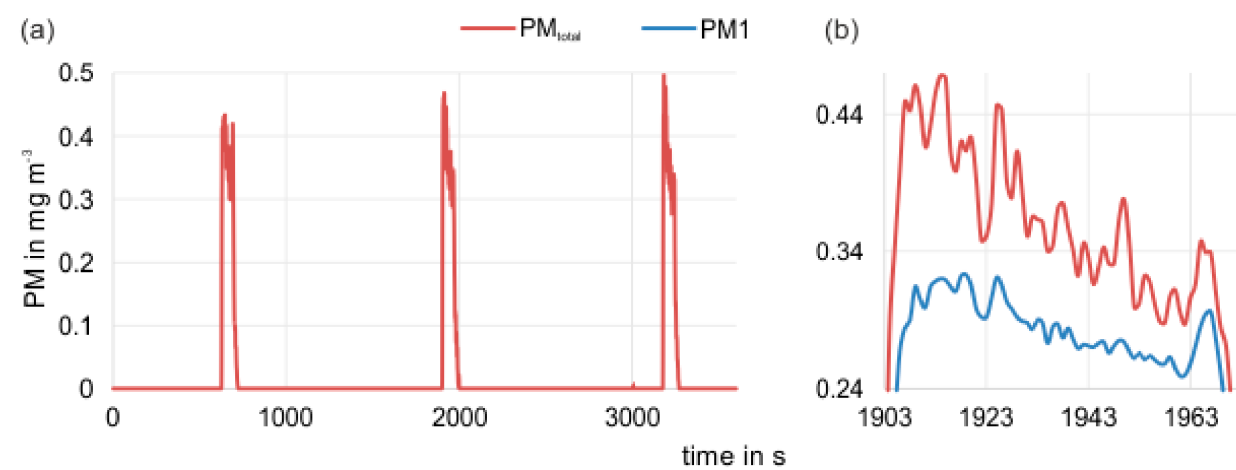

Figure 7. (a) Particulate matter (PM) total during irrigation intervals at BTF clean air outlet (I-2) without demister. (b) Magnification of second irrigation interval from (a) with a focus on PM total and PM1 fractions.

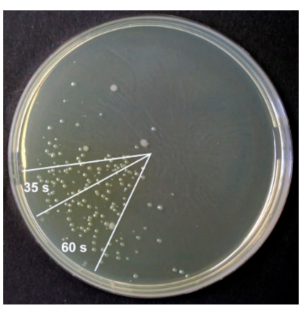

(a)

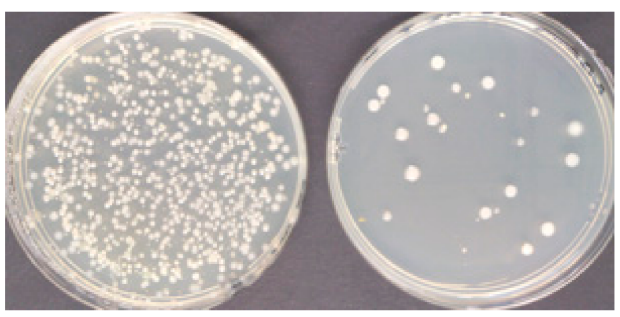

(c)

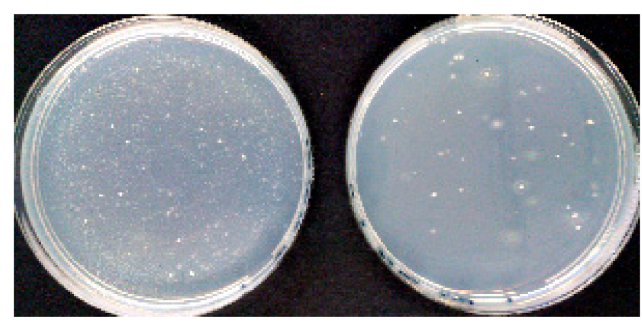

(e)

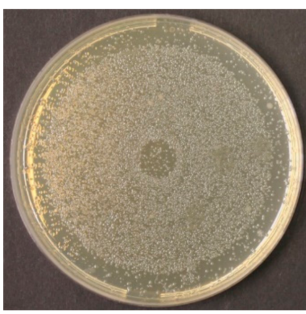

(b)

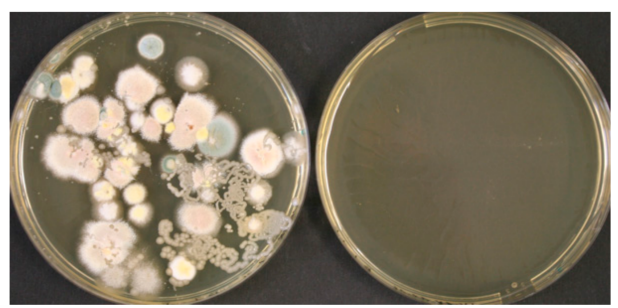

(d)

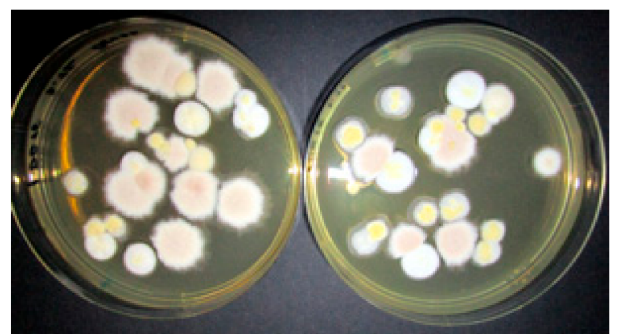

(f)

Figure 8. (a) Nutrient broth (NB) agar plate with bacterial colonies measured at I-2 with a slit-to-agar impactor. One minute of sampling equals a section of $36^{\circ}$, rotation $\mathrm{ccw}$. Indicated sections show the irrigation interval (60 s) and consecutive aerosol release (35 s). Colonies outside the sections can be assigned to impacts from lateral gas flow; (b) NB agar plate with bacterial colonies measured at I-2 with a slit-to-agar impactor, capturing the emissions of a two-week-old demister. The diameter of the dense "ring" of colonies indicates the width of the slit of the impactor; (c) NB agar plates without (left) and with (right) DBD-plasma treatment in by-pass mode of operation at specific input energy $(\mathrm{SIE})=8.18 \mathrm{kWh} 1000 \mathrm{~m}^{-3}$; (d) Dichloran-glycerol (DG18) agar plates without (left) and with (right) DBD-plasma treatment in inline mode of operation at SIE $=20.7 \mathrm{kWh} 1000 \mathrm{~m}^{-3}$; (e) NB and DG18 (f) agar plates for capturing of bacteria and fungi without (left) and with (right) corona plasma treatment at SIE $=8 \mathrm{kWh} 1000 \mathrm{~m}^{-3}$. 
A common and easy-to-implement (bio)aerosol reduction method would be a demister. A knitted fabric of PP fibers (see Section 2.2. Plasma Generators) was inserted into the piping, directly above the top lid of the BTF column. Neither particulate matter nor CFU could be measured afterwards (data not shown). However, without maintenance, a demister serves as just another filling material with high specific surface and perfect moistening. Inevitably, microorganisms started to settle and grow, changing the hydraulic properties of the demister, and transforming it into a permanent source of bioaerosols. This can be seen in Figure 8b, where a slit-to-agar measurement captured the emission of a demister which was two weeks into its use. Colonies, densely packed, spread evenly among the NB agar plate. Therefore, a cleaning or change of demisters on a regular basis must be implemented into the maintenance protocol, or a different method for eliminating bioaerosols has to be installed.

\subsubsection{Sterilization: DBD-Plasma}

Sterilization with DBD plasma was tested in inline and by-pass configuration (see Figure 1a,b). For inline configuration, a diluting auxiliary gas stream of clean air, that was mixed pre-plasma with the air stream from the BTF was necessary to secure stable plasma operation. For by-pass configuration, an auxiliary gas stream of clean air was also treated by the plasma and brought reactive species into the air stream from the BTF. Results for inline operation are shown in Table 3, and results for by-pass operation are shown in Table 4 . CFU numbers are mean values from 2-4 samples per day at 3-5 different days during a variable period of the same volume flow $\mathrm{Q}_{1}$ (for time frames compare respective columns of Tables 3 and 4 with Figure 3). Dilution factors (auxiliary flow and sampling) and losses through adhesion of cells on the ducts were considered.

It can be deduced from the results from inline and by-pass operation mode, that with increasing SIE value the sterilization efficiency increases as well, as is to be expected. A reduction in germ emissions by $1-4 \log$ units for inline mode could be achieved, while under comparable operating conditions, the sterilization efficiency in by-pass operation was about $0.9-1.5 \log$ stages lower. This leads to the assumption, that ozone is the main sterilization agent.

As shown in Figure 5, an increase in SIE resulted in an increased ozone output. The increase in the diluting volume flow $\left(\mathrm{Q}_{2}\right)$ in by-pass mode of operation had no detectable influence on sterilization efficiency. It can be assumed that there was no increase in ozone generation from more educt oxygen available from the air, or less ozone generation from the decreased EBRT of oxygen in the plasma. Further research needs to be carried out to elucidate the prevalent effect.

Table 3. Sterilization of bacteria and fungi with DBD plasma in inline mode at a given SIE (kWh $\left.1000 \mathrm{~m}^{-3}\right)$; EBRT (s) in plasma; $\mathrm{Q}_{1}$ : flow from BTF $\left(\mathrm{m}^{3} \mathrm{~h}^{-1}\right)$; $\mathrm{Q}_{2}$ : auxiliary flow $\left(\mathrm{m}^{3} \mathrm{~h}^{-1}\right)$; calculated $\mathrm{O}_{3}$

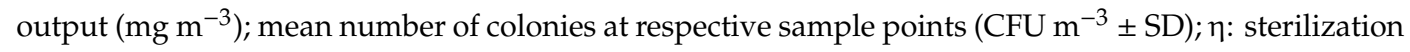
efficiency (\%). SD: standard deviation, $n \geq 6$. ${ }^{*}$ Dilution factorization cannot be applied, therefore value might be higher.

\begin{tabular}{cccccccc}
\hline $\mathbf{Q}_{\mathbf{1}}$ & $\mathbf{Q}_{\mathbf{2}}$ & SIE & EBRT & O $_{\mathbf{3}}$ Output & Pre DBD I-2 & Post DBD I-3 & $\eta$ \\
\hline & & & & \multicolumn{4}{c}{ bacteria } \\
\hline 50 & 23.5 & 5.9 & 0.46 & 74 & $6209 \pm 452$ & $723 \pm 48$ & 88.34 \\
\hline 60 & 23.5 & 8.4 & 0.40 & 166 & $7986 \pm 481$ & $254 \pm 26$ & 96.82 \\
\hline 50 & 23.5 & 10.4 & 0.46 & 184 & $6180 \pm 546$ & $123 \pm 12$ & 98.01 \\
\hline 50 & 23.5 & 20.7 & 0.46 & 443 & $6125 \pm 431$ & $0 *$ & 100 \\
\hline & & & & \multicolumn{4}{c}{ fungi } \\
\hline 50 & 23.5 & 10.4 & 0.46 & 184 & $3801 \pm 242$ & $81 \pm 13$ & 97.86 \\
\hline 50 & 23.5 & 20.7 & 0.46 & 443 & $3626 \pm 255$ & $0 *$ & 100 \\
\hline
\end{tabular}


Table 4. Sterilization of bacteria and fungi with DBD plasma in by-pass mode at a given SIE (kWh $\left.1000 \mathrm{~m}^{-3}\right) ; \mathrm{Q}_{1}$ : flow from BTF $\left(\mathrm{m}^{3} \mathrm{~h}^{-1}\right) ; \mathrm{Q}_{2}$ : auxiliary flow $\left(\mathrm{m}^{3} \mathrm{~h}^{-1}\right)$; calculated $\mathrm{O}_{3}$ output of $74 \mathrm{mg}$

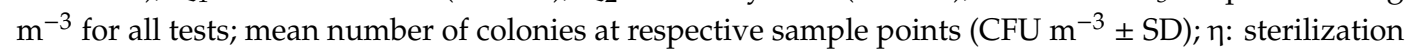
efficiency (\%). SD: standard deviation, $n \geq 6$.

\begin{tabular}{cccccc}
\hline$Q_{1}$ & $Q_{2}$ & SIE & Pre DBD I-2 & Post DBD I-3 & $\eta$ \\
\hline \multicolumn{7}{c}{ bacteria } \\
\hline 40 & 8.9 & 8.18 & $4383 \pm 458$ & $1027 \pm 24$ & 76.57 \\
\hline 50 & 8.9 & 6.79 & $6357 \pm 482$ & $2578 \pm 61$ & 59.44 \\
\hline 60 & 8.9 & 5.81 & $8188 \pm 490$ & $4610 \pm 73$ & 43.70 \\
\hline 40 & 11.4 & 7.78 & $4616 \pm 483$ & $1159 \pm 20$ & 74.89 \\
\hline 60 & 11.4 & 5.60 & $8071 \pm 533$ & $4308 \pm 81$ & 46.62 \\
\hline \multicolumn{7}{c}{} \\
\hline 50 & 8.9 & 6.79 & $4975 \pm 290$ & $1915 \pm 47$ & 61.50 \\
\hline
\end{tabular}

Furthermore, pre-DBD CFU data for bacteria in by-pass operation mode increased with increasing volume flow. With increasing kinetic energy, more aerosols and therefore more microorganisms can be carried by the air stream.

The sterilization efficiency for fungi was expected to be lower than the efficiency for bacteria, due to the fungal trait of being able to form durable spores. Overall, more experiments have to be conducted to see statistical trends.

\subsubsection{Sterilization: Corona Plasma}

Sterilization with corona plasma was tested in the inline configuration at a flow rate of $50 \mathrm{~m}^{3} \mathrm{~h}^{-1}$ (see Figure 1c). Output power was fixed at $400 \mathrm{~W}$, resulting in an SIE of $8 \mathrm{kWh} 1000 \mathrm{~m}^{-3}$. Due to a short period of availability of the corona plasma generator, only limited numbers of tests were carried out. Exemplary results can be seen in Figure 8 for bacteria (e) and fungi (f). Corona plasma sterilization efficiency was lower than DBD-plasma, although corona SIE value resided in the range of the tested DBD SIE values. The lower performance can be traced back to a much lower plasma homogeneity and hence lower ozone output, compared to the electrode plates from the DBD-plasma.

\subsection{Synergistic Effects of the Combined System}

BTF and DBD are both versatile systems for VOC abatement, but while a BTF can struggle with variations in inlet concentration and produces unwanted secondary germ emissions, a DBD is too costly at high volume flows and permanent operation. The two systems can be combined and operated in different orders to harness synergistic effects: BTF or DBD first.

When the DBD is put first, parts of the lipophilic waste air component are transformed to more hydrophilic compounds by the plasma (see Section 3.2.3). Due to a higher bioavailability and easier degradability of the metabolites in the BTF, a higher overall removal efficiency can be expected. However, this configuration has a high energy demand from constant DBD uptime, as well as germ emissions from the BTF preventing a potential re-use of the process air. When the BTF is put first, the system lacks the potentiating effect in VOC abatement compared to the reverse configuration. However, this makes sterilization of the waste air possible, which allows for the re-use of processed air. As shown in Section 3.3.1, the secondary treatment step only has to take place during irrigation. In addition to energy savings from the re-use, SIE can be decreased by up to $90 \%$ from a clocked operation of the DBD. Advantages and disadvantages of the combined system are summarized in Table 5. 
Table 5. Advantages of the combined system and limitations of previous technology for the treatment of styrene-containing waste air and bioaerosols.

\begin{tabular}{|c|c|c|}
\hline Treatment & Advantages & Disadvantages \\
\hline Biotrickling filter & $\begin{array}{l}\text { Low operational costs } \\
\text { Durability of package material } \\
\text { Ease of process control (pH, salinity, } \\
\text { nutrients, absorbed VOC) } \\
\text { Compact construction } \\
\text { Easy elimination of microbial intermediates }\end{array}$ & $\begin{array}{l}\text { Potential accumulation of extended biomass } \\
\text { (Clogging) } \\
\text { Lack of adsorptive effects to increase the } \\
\text { bioavailability of waste gas compounds } \\
\text { More complex structure (compared to } \\
\text { biofilter) } \\
\text { Temporary generation of elutriation water } \\
\text { Germ emissions } \\
\text { Remaining contamination of waste gas with } \\
\text { VOCs, odor and germs }\end{array}$ \\
\hline Non-thermal plasma (NTP) & $\begin{array}{l}\text { High efficiency in germ reduction and odor } \\
\text { abatement } \\
\text { Partial/total oxidation of VOCs } \\
\text { Short start-up/shut-down times } \\
\text { Low pressure loss } \\
\text { Intermittent operation possible }\end{array}$ & $\begin{array}{l}\text { High energy demand } \\
\text { Sensitivity against dust and high moisture } \\
\text { Limited operational stability }\end{array}$ \\
\hline Combined process & $\begin{array}{l}\text { Low operational costs } \\
\text { Ease of process control } \\
\text { Compact construction } \\
\text { Effective elimination of VOCs, odor and } \\
\text { germ emissions } \\
\text { Re-use of processed air } \\
\text { On-demand use of NTP, hence high energy } \\
\text { efficiency }\end{array}$ & $\begin{array}{l}\text { More complex structure } \\
\text { Increased energy demand }\end{array}$ \\
\hline
\end{tabular}

\subsection{Summary of Results}

1. At an inlet concentration of about 340-360 $\mathrm{mg} \mathrm{C} \mathrm{m}^{-3}$, equivalent to $370-390 \mathrm{mg} \mathrm{m}^{-3}$ of styrene, efficiencies of $96-98 \%$ at EBRT of 24-50 s and elimination rates of 25.9-50.1 $\mathrm{g} \mathrm{C} \mathrm{m}^{-3} \mathrm{~h}^{-1}$ and 28.1-54.3 g styrene $\mathrm{m}^{-3} \mathrm{~h}^{-1}$ were achieved, respectively. In comparison to the literature data shown in Table 1, the elimination efficiency in the present study is higher by a factor of 1.5-5.5 than results of other studies handling similar process conditions and the absence of solubilizers. Only Song et al. (2012) achieved a comparable elimination efficiency of $56.9 \mathrm{~g} \mathrm{~m}^{-3}$ $\mathrm{h}^{-1}$ at $250 \mathrm{mg} \mathrm{m}^{-3}$, an EBRT of $30 \mathrm{~s}$, and RE of $87 \%$.

2. Variations in the irrigation density in the range of $0.153-1.02 \mathrm{~m}^{3} \mathrm{~m}^{-2} \mathrm{~h}^{-1}$, and thus differences in the thickness of the aqueous film covering the biofilm, showed no effect on the elimination efficiencies detected. Therefore, there was no limitation in the transport kinetics, but a limitation in the degradation kinetics.

3. The limitation in the degradation kinetics is also illustrated by an increase in RE after the addition of nitrogenous fertilizers. As an example, RE increased from $65 \%$ to almost $100 \%$ at day 85 after fertilizer application. Furthermore, RE nearly doubled using fertilizers with ammonium as a nitrogen source compared to urea, since the transformation of urea to ammonia by urease is not necessary.

4. Starvation periods due to weekend shutdowns were well tolerated by the system, and the efficiencies after start-up increased to almost total conversion within a few hours.

5. During operation of the BTF, germ emissions occurred almost exclusively during the irrigation interval and a short after-run phase of approx. $35 \mathrm{~s}$. As expected, the germ emissions increased with increasing gas flows.

6. The germ emissions can be reduced energy-efficiently by 2-3 log units during irrigation intervals, or nearly completely during interim phases by using a suitably designed demister. The removal efficiency of the demister strongly depends on its maintenance condition. Automation in cleaning can be realized by periodical high-pressure flushing with water, or an exchange of the demister 
unit and ex-situ regeneration for organic polymer models. Demisters made out of stainless steel might be equipped with a heater to periodically burn off biomass and vaporize locked-in water.

7. As expected, the downstream NTP stage achieved a further reduction in germ emissions by 1-4 log units, depending on the SIE values of the test.

8. Under comparable operating conditions, the sterilization efficiency in by-pass operation was about $0.9-1.5 \log$ stages lower than at inline operation.

9. Due to the high efficiency of the BTF stage it was not necessary to use the DBD for VOC abatement.

10. At comparable conditions, the efficiency of the corona discharge was significantly lower than that of the DBD. For example, at an SIE value of $8 \mathrm{kWh} 1000 \mathrm{~m}^{-3}$ total elimination of fungal emissions was observed in the DBD, while only $10 \%$ of the emissions were removed by corona discharge.

11. Flow simulations showed optimization potentials for a significant improvement of the contact between waste gas and plasma discharge, whereby used SIE-values can be lowered considerably in the future.

12. SIE can be further decreased by a clocked operation of the DBD set during irrigation and a limited after-run period. Hence, SIE values can be decreased by $90 \%$ at minimum in the present operational conditions of the BTF.

\section{Conclusions}

A biotrickling filter for treatment of styrene emissions was operated for 1220 days to show the effect in variation of relevant process parameters such as inlet concentration, starvation period, EBRT, type and dosage of fertilizer, and irrigation density on the removal efficiency of the system. Furthermore, the effect of these process conditions and maintenance intervals of the demister on germ emissions were monitored. The system was further equipped with an NTP stage in the downstream airflow to evaluate the sterilization efficiency with regards to NTP technology and SIE value.

In summary, it can be stated that the process combination of BTF and NTP stages has proven to be an energy-efficient process to eliminate styrene emissions as well as secondary emissions of microorganisms formed in the biological process, so that a technical recirculation of the treated air into production processes is possible. This approach allows a significant reduction in the occurring waste gas flows and the associated energy losses, especially during the heating period.

Author Contributions: Conceptualization, S.H., D.D. and K.-H.E.; methodology, S.H., D.D. and A.S.; software, S.H.; investigations, S.H., D.D. and A.S.; data curation, S.H. and A.S.; writing, S.H., D.D., A.S. and K.-H.E.; review and editing, D.D.; visualization, S.H., A.S.; supervision, K.-H.E.; project administration, D.D.; funding acquisition, D.D. All authors have read and agreed to the published version of the manuscript.

Funding: This research was funded by BMWi/AiF, grant number KF2015604RH3.

Acknowledgments: The authors would like to thank the PlasmaAir AG (Weil der Stadt-Hausen, Germany) for providing both the DBD and the corona plasma systems.

Conflicts of Interest: The authors declare no conflict of interest.

\section{References}

1. Rezaei, M.; Moussavi, G.; Naddafi, K.; Johnson, M.S. Enhanced biodegradation of styrene vapors in the biotrickling filter inoculated with biosurfactant-generating bacteria under $\mathrm{H} 2 \mathrm{O} 2$ stimulation. Sci. Total Environ. 2020, 704, 135325. [CrossRef] [PubMed]

2. German Federal Environmental Agency. Zusammenfassung des Technical Support. Document (TSD) zu: Styrol. 2003. Available online: https://www.umweltbundesamt.de/sites/default/files/medien/515/dokumente/ styrol.pdf (accessed on 2 November 2020).

3. OECD. SIAM 4 SIDS Initial Assessment Profile of Styrene (CAS 100-42-5). 1996. Available online: https://hpvchemicals.oecd.org/ui/handler.axd?id=17F54B62-0AED-473F-B210-B607AF65E8CF (accessed on 2 November 2020). 
4. HDIN Research. Styrene Monomer (SM) Production Capacity Reach to 36.7 Million Tons in 2018. Available online: https://www.hdinresearch.com/news/28 (accessed on 2 November 2020).

5. Vyskocil, A.; Thuot, R.; Turcot, A.; Gérin, M.; Viau, C. Peak exposures to styrene in Quebec fibreglass reinforced plastic industry. Natl. Inst. Work. Life 2001, 10, 316-318.

6. Webster, T.S.; Cox, H.H.J.; Deshusses, M.A. Resolving operational and performance problems encountered in the use of a pilot/full-scale biotrickling filter reactor. Environ. Prog. 1999, 18, 162-172. [CrossRef]

7. Lackey, L.W.; Gamble, J.R.; Holt, M.T. Feasibility Testing of Biofiltration Technology for Remediating Air Contaminated by a Boat Manufacturing Facility. J. Air Waste Manag. Assoc. 1998, 48, 527-536. [CrossRef] [PubMed]

8. Loy, J.; Flauger, M. Biological elimination of styrene contaminated waste gas with the Zander biotrickling technology. In Proceedings of the 89th Annual Meeting and Exhibition of Air and Waste Management Association, Nashville, TN, USA, 16-21 June 1996.

9. Tischler, D. Microbial Styrene Degradation; Springer International Publishing: Cham, Switzerland, 2015; ISBN 978-3-319-24862-2.

10. Mooney, A.; Ward, P.G.; O'Connor, K.E. Microbial degradation of styrene: Biochemistry, molecular genetics, and perspectives for biotechnological applications. Appl. Microbiol. Biotechnol. 2006, 72, 1. [CrossRef] [PubMed]

11. Panke, S.; Witholt, B.; Schmid, A.; Wubbolts, M.G. Towards a Biocatalyst for (S)-Styrene Oxide Production: Characterization of the Styrene Degradation Pathway of Pseudomonas sp. Strain VLB120. Appl. Environ. Microbiol. 1998, 64, 2032-2043. [CrossRef]

12. Oelschlägel, M.; Zimmerling, J.; Tischler, D. A Review: The Styrene Metabolizing Cascade of Side-Chain Oxygenation as Biotechnological Basis to Gain Various Valuable Compounds. Front. Microbiol. 2018, 9, 490. [CrossRef]

13. Teufel, R.; Mascaraque, V.; Ismail, W.; Voss, M.; Perera, J.; Eisenreich, W.; Haehnel, W.; Fuchs, G. Bacterial phenylalanine and phenylacetate catabolic pathway revealed. Proc. Natl. Acad. Sci. USA 2010, 107, 14390-14395. [CrossRef]

14. Fewson, C.A. Microbial metabolism of mandelate: A microcosm of diversity. FEMS Microbiol. Rev. 1988, 4, 85-110. [CrossRef]

15. Jorio, H.; Bibeau, L.; Heitz, M. Biofiltration of Air Contaminated by Styrene: Effect of Nitrogen Supply, Gas Flow Rate, and Inlet Concentration. Environ. Sci. Technol. 2000, 34, 1764-1771. [CrossRef]

16. San-Valero, P.; Álvarez-Hornos, J.; Ferrero, P.; Penya-Roja, J.M.; Marzal, P.; Gabaldón, C. Evaluation of Parallel-Series Configurations of Two-Phase Partitioning Biotrickling Filtration and Biotrickling Filtration for Treating Styrene Gas-Phase Emissions. Sustainability 2020, 12, 6740. [CrossRef]

17. Song, T.; Yang, C.; Zeng, G.; Yu, G.; Xu, C. Effect of surfactant on styrene removal from waste gas streams in biotrickling filters. J. Chem. Technol. Biotechnol. 2012, 87, 785-790. [CrossRef]

18. San-Valero, P.; Gabaldón, C.; Penya-Roja, J.M.; Quijano, G. Enhanced styrene removal in a two-phase partitioning bioreactor operated as a biotrickling filter: Towards full-scale applications. Chem. Eng. J. 2017, 309, 588-595. [CrossRef]

19. Zamir, S.M.; Babatabar, S.; Shojaosadati, S.A. Styrene vapor biodegradation in single- and two-liquid phase biotrickling filters using Ralstonia eutropha. Chem. Eng. J. 2015, 268, 21-27. [CrossRef]

20. Clothiaux, E.J.; Koropchak, J.A.; Moore, R.R. Decomposition of an organophosphorus material in a silent electrical discharge. Plasma Chem. Plasma Process. 1984, 4, 15-20. [CrossRef]

21. Fraser, M.E.; Sheinson, R.S. Electric discharge-induced oxidation of hydrogen cyanide. Plasma Chem. Plasma Process. 1986, 6, 27-38. [CrossRef]

22. Dobslaw, D.; Schulz, A.; Helbich, S.; Dobslaw, C.; Engesser, K.-H. VOC removal and odor abatement by a low-cost plasma enhanced biotrickling filter process. J. Environ. Chem. Eng. 2017, 5, 5501-5511. [CrossRef]

23. Dobslaw, D.; Ortlinghaus, O.; Dobslaw, C. A combined process of non-thermal plasma and a low-cost mineral adsorber for VOC removal and odor abatement in emissions of organic waste treatment plants. J. Environ. Chem. Eng. 2018, 6, 2281-2289. [CrossRef]

24. Fang, H.J.; Hou, H.Q.; Xia, L.Y.; Shu, X.H.; Zhang, R.X. A combined plasma photolysis (CPP) method for removal of CS2 from gas streams at atmospheric pressure. Chemosphere 2007, 69, 1734-1739. [CrossRef] [PubMed] 
25. Morgan, N.N. Atmospheric pressure dielectric barrier discharge chemical and biological applications. Int. J. Phys. Sci. 2009, 4, 885-892.

26. Schiavon, M.; Schiorlin, M.; Torretta, V.; Brandenburg, R.; Ragazzi, M. Non-thermal plasma assisting the biofiltration of volatile organic compounds. J. Clean. Prod. 2017, 148, 498-508. [CrossRef]

27. Mizuno, A. Industrial applications of atmospheric non-thermal plasma in environmental remediation. Plasma Phys. Control. Fusion 2007, 49, A1-A15. [CrossRef]

28. Müller, S.; Zahn, R.-J. Air Pollution Control by Non-Thermal Plasma. Contrib. Plasma Phys. 2007, 47, 520-529. [CrossRef]

29. Preis, S.; Klauson, D.; Gregor, A. Potential of electric discharge plasma methods in abatement of volatile organic compounds originating from the food industry. J. Environ. Manag. 2013, 114, 125-138. [CrossRef]

30. Liang, Y.; Wu, Y.; Sun, K.; Chen, Q.; Shen, F.; Zhang, J.; Yao, M.; Zhu, T.; Fang, J. Rapid inactivation of biological species in the air using atmospheric pressure nonthermal plasma. Environ. Sci. Technol. 2012, 46, 3360-3368. [CrossRef]

31. Korachi, M.; Turan, Z.; Şentürk, K.; Şahin, F.; Aslan, N. An investigation into the biocidal effect of high voltage AC/DC atmospheric corona discharges on bacteria, yeasts, fungi and algae. J. Electrost. 2009, 67, 678-685. [CrossRef]

32. Moreau, M.; Orange, N.; Feuilloley, M.G.J. Non-thermal plasma technologies: New tools for bio-decontamination. Biotechnol. Adv. 2008, 26, 610-617. [CrossRef]

33. Subrahmanyam, C.; Magureanu, M.; Renken, A.; Kiwi-Minsker, L. Catalytic abatement of volatile organic compounds assisted by non-thermal plasma. Appl. Catal. B Environ. 2006, 65, 150-156. [CrossRef]

34. Heller, L.C.; Edelblute, C.M.; Mattson, A.M.; Hao, X.; Kolb, J.F. Inactivation of bacterial opportunistic skin pathogens by nonthermal DC-operated afterglow atmospheric plasma. Lett. Appl. Microbiol. 2012, 54, 126-132. [CrossRef]

35. Steinberg, I.; Rohde, C.; Bockreis, A.; Jager, J. Increase of the purification efficiency of biofilters by the use of a complementary ionisation step. Waste Manag. 2005, 25, 375-381. [CrossRef] [PubMed]

36. Rafflenbeul, R. Nichtthermische Plasmaanlagen (NTP) zur Luftreinhaltung in der Abfallwirtschaft. Müll und Abfall 1998. [CrossRef]

37. Schiavon, M.; Scapinello, M.; Tosi, P.; Ragazzi, M.; Torretta, V.; Rada, E.C. Potential of non-thermal plasmas for helping the biodegradation of volatile organic compounds (VOCs) released by waste management plants. J. Clean. Prod. 2015, 104, 211-219. [CrossRef]

38. Wei, Z.S.; Li, H.Q.; He, J.C.; Ye, Q.H.; Huang, Q.R.; Luo, Y.W. Removal of dimethyl sulfide by the combination of non-thermal plasma and biological process. Bioresour. Technol. 2013, 146, 451-456. [CrossRef]

39. Jiang, L.; Li, H.; Chen, J.; Zhang, D.; Cao, S.; Ye, J. Combination of non-thermal plasma and biotrickling filter for chlorobenzene removal. J. Chem. Technol. Biotechnol. 2016, 91, 3079-3087. [CrossRef]

40. Jiang, L.; Li, S.; Cheng, Z.; Chen, J.; Nie, G. Treatment of 1,2-dichloroethane and n -hexane in a combined system of non-thermal plasma catalysis reactor coupled with a biotrickling filter. J. Chem. Technol. Biotechnol. 2018, 93, 127-137. [CrossRef]

41. Karatum, O.; Deshusses, M.A. A comparative study of dilute VOCs treatment in a non-thermal plasma reactor. Chem. Eng. J. 2016, 294, 308-315. [CrossRef]

42. Kim, H.; Han, B.; Hong, W.; Ryu, J.; Kim, Y. A New Combination System Using Biotrickling Filtration and Nonthermal Plasma for the Treatment of Volatile Organic Compounds. Environ. Eng. Sci. 2009, 26, 1289-1297. [CrossRef]

43. Jiang, L.; Zhu, R.; Mao, Y.; Chen, J.; Zhang, L. Conversion characteristics and production evaluation of styrene/o-xylene mixtures removed by DBD pretreatment. Int. J. Environ. Res. Public Health 2015, 12, 1334-1350. [CrossRef]

44. Zhu, R.; Mao, Y.; Jiang, L.; Chen, J. Performance of chlorobenzene removal in a nonthermal plasma catalysis reactor and evaluation of its byproducts. Chem. Eng. J. 2015, 279, 463-471. [CrossRef]

45. Mäule, J.; Reiser, M.; Kranert, M. Neue Techniken zur Abgasreinigung in der Abfallwirtschaft durch Nichtthermische Plasmatechnologie: Verfahrenskombination aus Biofilter und NTP-Technologie. Abschlussbericht zum DBU-Forschungsvorhaben 17988; No. 17988; Universität Stuttgart: Stuttgart, Germany, 2005.

46. Hołub, M.; Brandenburg, R.; Grosch, H.; Weinmann, S.; Hansel, B. Plasma Supported Odour Removal from Waste Air in Water Treatment Plants: An Industrial Case Study. Aerosol Air Qual. Res. 2014, 14, 697-707. [CrossRef] 
47. Gąszczak, A.; Bartelmus, G.; Burghardt, A.; Rotkegel, A.; Sarzyński, R. Experiments and modelling of a biotrickling filter (BTF) for removal of styrene from airstreams. J. Chem. Technol. Biotechnol. 2018, 93, 2659-2670. [CrossRef]

48. San-Valero, P.; Dorado, A.D.; Martínez-Soria, V.; Gabaldón, C. Biotrickling filter modeling for styrene abatement. Part 1: Model development, calibration and validation on an industrial scale. Chemosphere 2018, 191, 1066-1074. [CrossRef]

49. Runye, Z.; Christian, K.; Zhuowei, C.; Lichao, L.; Jianming, Y.; Jianmeng, C. Styrene removal in a biotrickling filter and a combined UV-biotrickling filter: Steady- and transient-state performance and microbial analysis. Chem. Eng. J. 2015, 275, 168-178. [CrossRef]

50. Sun, Z.; Yang, B.; Wang, L.; Ding, C.; Li, Z. Toluene-styrene secondary acclimation improved the styrene removal ability of biotrickling filter. Chem. Speciat. Bioavailab. 2017, 29, 54-59. [CrossRef]

51. Chuang, F.-J.; Chou, M.-S.; Chang, H.-Y. Biotrickling filtration of airborne styrene: A comparison of filtration media. J. Air Waste Manag. Assoc. 2018, 68, 369-376. [CrossRef]

52. Álvarez-Hornos, F.J.; Martínez-Soria, V.; Marzal, P.; Izquierdo, M.; Gabaldón, C. Performance and feasibility of biotrickling filtration in the control of styrene industrial air emissions. Int. Biodeterior. Biodegrad. 2017, 119, 329-335. [CrossRef]

53. Rene, E.R.; Veiga, M.C.; Kennes, C. Biodegradation of gas-phase styrene using the fungus Sporothrix variecibatus: Impact of pollutant load and transient operation. Chemosphere 2010, 79, 221-227. [CrossRef]

54. Bak, A.; Kozik, V.; Dybal, P.; Sulowicz, S.; Kasperczyk, D.; Kus, S.; Barbusinski, K. Abatement robustness of volatile organic compounds using compact trickle-bed bioreactor: Biotreatment of styrene, ethanol and dimethyl sulfide mixture in contaminated airstream. Int. Biodeterior. Biodegrad. 2017, 119, 316-328. [CrossRef]

55. Rene, E.R.; Montes, M.; Veiga, M.C.; Kennes, C. Styrene removal from polluted air in one and two-liquid phase biotrickling filter: Steady and transient-state performance and pressure drop control. Bioresour. Technol. 2011, 102, 6791-6800. [CrossRef] [PubMed]

56. Sempere, F.; Martínez-Soria, V.; Palau, J.; Penya-Roja, J.-M.; San-Valero, P.; Gabaldón, C. Effects of nitrogen source and empty bed residence time on the removal of styrene gaseous emissions by biotrickling filtration. Bioprocess. Biosyst. Eng. 2011, 34, 859-867. [CrossRef] [PubMed]

57. Kim, D.; Cai, Z.; Sorial, G.A. Evaluation of trickle-bed air biofilter performance under periodic stressed operating conditions as a function of styrene loading. J. Air Waste Manag. Assoc. 2005, 55, 200-209. [CrossRef]

58. Kraakman, N.; van Groenestijn, J.W.; Koers, B.; Heslinga, D.C. Mededelingen Faculteit Lanbouwkundige en Toegepaste Biologische Wetenschapper. Univ. Gent Belg. 1997, 62, 1535-1541.

59. Cox, H.H.J.; Magielsen, F.J.; Doddema, H.J.; Harder, W. Influence of the water content and water activity on styrene degradation by Exophiala jeanselmei in biofilters. Appl. Microbiol. Biotechnol. 1996, 45, 851-856. [CrossRef]

60. Arnold, M.; Reittu, A.; Wright, A. von; Martikainen, P.J.; Suihko, M.L. Bacterial degradation of styrene in waste gases using a peat filter. Appl. Microbiol. Biotechnol. 1997, 48, 738-744. [CrossRef]

61. Hartmans, S.; Tramper, J.; Bont, J.d. Biological waste air treatment. In Proceedings of the 5th European Congress on Biotechnology; Muncksgaard International Publisher: Kopenhagen, Denmark; 1990.

62. Windsperger, A.; Buchner, R.; Stefan, K. k.A. Reinigung lösemittelhaltiger Abluft mit Biofiltern-Teil 1: Laboruntersuchungen und Ergebnisse aus verschiedenen Industriezweigen. Staub-Reinhalt. Der Luft 1990, 50, 465-470.

63. Togna, A.P.; Folsom, B.R. Removal of styrene from air using bench-scale biofiler and biotrickling filter reactors. In Proceedings of the 85th Annual Meeting of Air and Waste Management Association, Kansas City, MO, USA, 21-26 June 1992.

64. Fortschritte in der Biofiltertechnologie. Vortrag und Poster Anlässlich des Internationalen Kongresses "Geruchsstoffemissionen-Probleme und Lösungsmöglichkeiten", Ljubiljana, Slowenien; Sabo, F., Pelic-Sabo, M., Wurmthaler, J., Mössinger, M., Eds.; VDI Verlag: Düsseldorf, Germany, 1993.

65. Cox, H.H.J.; Moerman, R.E.; van Baalen, S.; van Heiningen, W.N.M.; Doddema, H.J.; Harder, W. Performance of a styrene-degrading biofilter containing the yeast Exophiala jeanselmei. Biotechnol. Bioeng. 1997, 53, 259-266. [CrossRef]

66. Woiski, C.; Dobslaw, D.; Engesser, K.-H. Isolation and characterization of 2-butoxyethanol degrading bacterial strains. Biodegradation 2020, 31, 153-169. [CrossRef] [PubMed] 
67. Kommission Reinhaltung der Luft im VDI und DIN-Normenausschuss KRdL. Messen von Partikeln—Staubmessung in Strömenden Gasen. Gravimetrische Bestimmung der Staubbeladung; Beuth Verlag GmbH: Berlin, Germany, 2006.

68. DeMore, W.B.; Patapoff, M. Comparison of ozone determinations by ultraviolet photometry and gas-phase titration. Environ. Sci. Technol. 1976, 10, 897-899. [CrossRef]

69. Araya, P.; Chamy, R.; Mota, M.; Alves, M. Biodegradability and toxicity of styrene in the anaerobic digestion process. Biotechnol. Lett. 2000, 22, 1477-1481. [CrossRef]

70. Grbić-Galić, D.; Churchman-Eisel, N.; Mraković, I. Microbial transformation of styrene by anaerobic consortia. J. Appl. Bacteriol. 1990, 69, 247-260. [CrossRef]

71. Dobslaw, D.; Woiski, C.; Winkler, F.; Engesser, K.-H.; Dobslaw, C. Prevention of clogging in a polyurethane foam packed biotrickling filter treating emissions of 2-butoxyethanol. J. Clean. Prod. 2018, 200, 609-621. [CrossRef]

72. Wojtowicz, J.A. Ozone. In Kirk-Othmer Encyclopedia of Chemical Technology; Othmer, K., Ed.; John Wiley \& Sons, Inc.: Hoboken, NJ, USA, 2000; ISBN 9780471238966.

Publisher's Note: MDPI stays neutral with regard to jurisdictional claims in published maps and institutional affiliations.

(C) 2020 by the authors. Licensee MDPI, Basel, Switzerland. This article is an open access article distributed under the terms and conditions of the Creative Commons Attribution (CC BY) license (http://creativecommons.org/licenses/by/4.0/). 